THE MÔN-DEEMSTER-RIBBLESDALE FOLD-THRUST BELT, CENTRAL UK: A VARISCAN INVERSION BELT LOCATED ON WEAK CALEDONIAN CRUST.

\author{
Tim Pharaoh ${ }^{1}$, Richard Haslam ${ }^{1}$, Ed Hough ${ }^{1}$, Karen Kirk ${ }^{1}$, Graham Leslie ${ }^{2}$, Dave Schofield ${ }^{2}$ \& Adrian \\ Heafford $^{3}$
}

1. British Geological Survey, Environmental Science Centre, Keyworth, Nottingham, NG12 5GG

2. British Geological Survey, The Lyell Centre, Research Avenue South, Edinburgh, EH14 4AP

3. International Subsurface Information, IHS Markit, 25 Ropemaker Street, London, EC2Y 9LY

\begin{abstract}
The Ribblesdale Fold belt, representing the Variscan inversion of the Bowland Basin, is a well-known geological feature of northern England. It represents a crustal strain discontinuity between the graniteunderpinned basement highs of the northern Pennines and Lake District in the north, and the Central Lancashire High/southern Pennines, in the south. Recent seismic interpretation and mapping has demonstrated that the Ribblesdale Fold belt continues offshore towards Anglesey via the Deemster Platform, beneath the Permo-Triassic sedimentary cover of the southern part of the East Irish Sea Basin. The Môn-Deemster Fold-Thrust Belt (FTB) affects strata of Mississippian to late Pennsylvanian age. Variscan thrusts extend down into the pre-Carboniferous basement but apparently terminate at a lowangle detachment deeper in the crust, here correlated with the strongly sheared Penmynydd Zone exposed in the adjacent onshore. Up to $15 \%$ shortening is observed on seismic sections across the FTB offshore, but is greater in the strongly inverted onshore segment. Pre-Carboniferous thrusting postdates formation of the Penmynydd Zone, and is likely of Acadian age, when basement structures such as the southward-vergent Carmel Head Thrust formed. Extensional reactivation of the Acadian structures in early Mississippian time defined the northern edge of the offshore Bowland Basin. The relatively late brittle structures of the Menai Strait Fault System locally exhume the Penmynydd Zone and define the southern edge of the basin. The longer seismic records from the offshore provide insights to the tectonic evolution of the more poorly imaged FTB onshore.
\end{abstract}

The regional Caledonian basement structure and terrane context of the area investigated is depicted in Fig. 1. The Ribblesdale Fold belt was first recognised by Phillips (1836). Subsequently, the structures were described and interpreted by a number of authors, notably Hudson \& Mitchell (1937) and Moseley (1956, 1972). Detailed mapping was carried out by BGS in the latter part of the $20^{\text {th }} \mathrm{C}$ (Earp et al. 1961, Arthurton et al. 1988, Aitkenhead et al. 1992, and Brandon et al. 1988). Regional syntheses were provided by Arthurton et al. (1988), and in the context of the seismic reflection dataset, by Kirby et al. (2000). Nowadays the fold belt is recognised as a series of inversion structures (folds, thrusts and reverse faults) developed during the late Pennsylvanian Variscan Orogeny, reflecting inversion of the Bowland Basin, formed by extension in preceding Mississippian time. The Bowland Basin forms part of the wider Craven Basin complex (Hudson 1933, Gawthorpe 1987, Kirby et al. 2000). The thick organic-rich shale sequence of the latter (Bowland Shale Group) is now recognised to have significant potential as an unconventional hydrocarbon resource (Smith et al. 2010, DECC 2010, Andrews 2013; 
Clarke et al. 2018). Continuity of the fold belt (and ancestral basin) into the offshore of the Irish Sea has been postulated on a speculative basis by numerous authors (e.g. Jackson et al. 1995, Corfield et al. 1996, Kirby et al. 2000, Woodcock \& Strachan 2012) but was first convincingly demonstrated by Pharaoh et al. (2016b, 2018) during the course of a review of Palaeozoic prospectivity in the Irish Sea for the $21^{\text {st }} \mathrm{C}$ Exploration Roadmap Project (for a DECC/OGA/industry consortium). The location of exploration wells suggests that the prospectivity of the concealed fold belt has nevertheless long been recognised by the hydrocarbon industry.

The Caledonian basement is well exposed around the margins of the Irish Sea region, in the North Wales and Lake District massifs (Fig. 2), but within the Carboniferous basin complex is only exposed in the small (Craven) inliers at Ingleton and Horton, in the central Pennines (Fig. 2). The geology of Anglesey and the Llŷn Peninsula was first comprehensively mapped and described by Greenly (1919) and Matley (1928). For much of the $20^{\text {th }} \mathrm{C}$, the largely unfossiliferous and 'exotic' rocks of Anglesey were regarded as being of Precambrian age (e.g. Shackleton, 1975). However, the discovery of fossils (Muir et al. 1979), improved lithostratigraphical correlation (Tiezsch-Tyler \& Phillips 1989) and the introduction of new tectonic concepts (e.g. Gibbons 1987, Gibbons \& Horak 1996) in the Irish Sea region has led to a major re-evaluation in the past 30 years. In particular, the Monian Complex of Anglesey is now recognised to comprise a tectonostratigraphic complex of crustal slices with protolith ages ranging from $616 \mathrm{Ma}$ (Neoproterozoic) to Cambrian, accreted onto the margin of the Gondwana Supercontinent in Tremadocian time (van Staal et al. 1998, Schofield et al. 2008, 2016, Waldron et al. 2018). The strong pre- late Ordovician deformation of the Ingleton Group of the Craven Inliers, predating a later, weaker deformation of Acadian (mid Devonian) age, has been documented by Soper \& Dunning (2005).

\section{Variscan FTB}

\section{a. Ribblesdale Fold-thrust belt (FTB)}

The FTB comprises an en échelon set of folds and thrusts affecting strata of Tournaisian to early Namurian age, exposed in the Bowland Fells of North Lancashire (Figs. 3, 4a). The axial traces of tight NE-SW-trending anticlines are more easily mapped than those of the more open intervening synclines. For this reason, and also for clarity, the synclinal traces are not shown on Fig. 3. Crosscutting faults trend NW-SE, including the South Craven Fault System (Arthurton 1984). The FTB extends ENEWSW for at least $80 \mathrm{~km}$, and is up to $25 \mathrm{~km}$ wide. It lies between the Askrigg Block to the north, and the Pennine and Rossendale blocks (Miller \& Grayson 1982) to the south (Fig. 2). It was uplifted in Stephanian time, and deeply eroded before the deposition of Permo-Triassic sandstones in the Clitheroe area (Earp et al. 1961) and in the Fylde and Formby areas (Fig. 2).

The anticlines have an axial length of 5-10 km and an amplitude $>1 \mathrm{~km}$, and many have steep NW limbs, reflecting a northwestward vergence. Many exhibit periclinal geometry. The Sykes and Catlow anticlines form an en échelon pair of complex structures just south of the postulated northern basin margin, at the Bowland Line (Fig. 4a). Both folds are inferred to have developed as a result of reversal of the underlying basin margin normal fault (Arthurton et al. 1988, Kirby et al. 2000). A reverse fault cuts the steep NW limb of the Catlow Anticline. The axial trace of the Thornley Anticline (Fig. 4b), farther west, is at least $11 \mathrm{~km}$ in length, and is also inferred to overlie an inferred normal fault at the northern edge of the basin. The shortening at the base Visean level is estimated at 10\% (Arthurton, 1984). Disharmonic folding between the upper and lower parts of folds, as a result of detachment within 
the Bowland Shale, is frequently recognised (Kirby et al. 2000). Along strike to the east, the Lothersdale Anticline (Fig. 4c), with a maximum amplitude of $1500 \mathrm{~m}$, is cut by reverse faults on both limbs. Both the Pendle Monocline and the Lothersdale Anticline form part of the Pendle Fault System, the inferred southern basin marginal fault (Kirby et al., 2000), which also underwent reversal during the Variscan inversion.

Reflection seismic data across the Ribblesdale FTB (Fig. 5) typically have a $3 \mathrm{~s}$ TWTT record length (very occasionally $4 \mathrm{~s}$ TWTT), which is insufficient to image the pre-Carboniferous basement, particularly where a cover of Permo-Triassic strata is present. In addition, the lines are generally short, so that it is difficult to profile the entire belt. The UKOGL regional line compilation RG-006 (Butler \& Jamieson, 2013) is valuable for correlation purposes despite its strongly oblique orientation. The southern margin of the FTB is associated with the south-facing Pendle Monocline (Figs. 3, 5b), with up to $2000 \mathrm{~m}$ amplitude and dips of $50-70^{\circ}$. The latter represents the inversion of an underlying Mississippian extensional fault, the Pendle Fault. Several of the structures within the FTB, including the Lothersdale, Dinkley, Swinden and Clitheroe anticlines, have the appearance of positive flower structures on seismic data, indicative of transpressional deformation (Kirby et al. 2000). The Clitheroe Anticline is markedly asymmetrical, with a locally overturned northern limb, and lies in the hangingwall of the northward-vergent Horrockford Hall Thrust (Kirby et al. 2000). The latter has a local displacement of $650 \mathrm{~m}$ (Earp et al. 1961) and is probably antithetic to the Pendle Fault.

In the adjacent Harrogate Basin, the Skipton Anticline (Hudson \& Mitchell 1937) is one of the largest inversion anticlines in the region, with an amplitude $>1500 \mathrm{~m}$, and extending ENE for $11 \mathrm{~km}$ from the South Craven Fault System (Kirby et al. 2000). The Skipton Rock Fault, a NNW-dipping, high-angle reverse fault, extends along the axial zone of the structure and was inferred by Arthurton (1984) to postdate formation of the anticline. The structure is inferred to overlie the continuation of the SE margin of the FTB into the Harrogate Basin.

Another feature of the Ribblesdale FTB is the presence of several NW-SE-trending crosscutting steep faults, e.g. the Clitheroe-Abbeystead, Barnoldswick, and South Craven faults (Fig. 3), which appear to truncate several of the inversion anticlines described above (Kirby et al. 2000). On seismic data, the Clitheroe-Abbeystead and Barnoldswick Fault have the appearance of positive flower structures with variable sense of throw along strike, suggesting a degree of oblique or transcurrent motion. They also appear to offset sinistrally some of the major basin-bounding syndepositional normal faults. As they control the facies and thickness of Mississippian strata, and compartmentalise the basin, they are interpreted as transfer faults active both during Mississippian subsidence, as well as during Variscan inversion (Kirby et al. 2000). The South Craven-Morley Campsall Fault System appears to have played a similar role, offsetting the Mississippian depocentres of the Bowland and Harrogate basins dextrally by perhaps $15 \mathrm{~km}$ (Figs. 3, 4a and 7), and compartmentalising subsequent Variscan inversion.

Arthurton (1984) inferred that the Sykes and Catlow anticlines formed as a consequence of dextral wrenching on an underlying basement fracture. Turner (1936) suggested that the trend of the folds might be posthumous on Caledonide basement trends, a concept with which Arthurton (1984) concurred. Arthurton (op.cit.) inferred that folding occurred episodically throughout much of Mississippian time, culminating in a late Pendleian phase of folding, particularly affecting the Catlow Anticline, and manifested in a marked unconformity of Arnsbergian age beneath the Grassington Grit (Brandon et al. 1998). Attenuation of the late Visean and Namurian sequences across regional highs associated with the anticlines is observed in the Fylde district (Clarke et al. 2018). Arthurton (op. cit.) and Arthurton et al. (1988) inferred from the pattern of en échelon folding, faulting and local unconformity that the FTB developed in a regional dextral shear regime operating throughout Mississippian time. However, the 
seismic data show that any syndepositional development of the anticlines was insignificant compared to subsequent regional shortening and uplift due to Variscan deformation (Corfield et al. 1996, Kirby et al. 2000). During subsequent erosion, up to $4000 \mathrm{~m}$ of strata may have been removed from the anticlinal cores (Kirby et al. 2000). Further inversion, associated with subsidence during the Mesozoic was controlled by several burial-uplift events (e.g. Barrett 1988, de Pater \& Baisch 2011, Andrews 2013).

\section{b. Môn-Deemster FTB}

The presence of a pre-Permian fold-thrust belt in the southern part of the East Irish Sea was reported by Pharaoh et al. (2016a, b, 2018). In contrast to the onshore, seismic reflection data records offshore are longer, typically $4 \mathrm{~s}$ TWTT or more (Fig. 6). The interpretations presented in Fig. 6 are however poorly constrained by the limited number of boreholes penetrating deep into the Carboniferous sequence (Fig. 3). Offshore only four wells (110/7b-06, 110/11-1, 110/15-6 and 113/27-2) enter late Mississippian strata in the area of interest, and none reach the Caledonian basement. Onshore, four wells (Roddlesworth-1, Holme Chapel-1, Wessenden-1, Silverdale-1) reach the Caledonian basement in the area of interest (Fig. 3). As a consequence, the seismic interpretations presented are driven by seismostratigraphic principles, supported by a close mesh of lines interpreted on a rapid, reconnaissance level of mapping (Pharaoh et al. 2016a). The folding and thrusting which manifestly affect Millstone Grit Group (Namurian) and Pennine Coal Measures Supergroup (Westphalian) strata extend downward into the Carboniferous Limestone Supergroup (Tournaisian-Visean), although the base of this sequence is poorly imaged. Thus, it is not possible to say if late Devonian strata are present, and involved in the deformation. The youngest strata affected by the folding appear to be of mid-Westphalian age although regional considerations suggest that the deformation is likely of late Westphalian age, attributed to the later stages of the Variscan Orogeny (Pharaoh et al. 2016b, 2018). Permian strata of the Appleby Group (=Collyhurst Sandstone) of Wordian age (c. $267 \mathrm{Ma}$ ), rest discordantly upon the truncated Variscan structure (Fig. 6a), although locally show evidence for antecedent folding (Suess, 1911) during later, Alpine inversion (Pharaoh et al. 2018).

Four parallel WSW-ENE trending anticlinal culminations are mapped in the area between the Anglesey High and the Deemster Platform (Figs. 2, 3 and 7), using both 2D and 3D seismic reflection datasets (Pharaoh et al. 2016b). Rapid variation in fold amplitude between seismic profiles indicates noncylindrical geometry. As onshore, the axial traces of the more open synclines are less easily mapped with precision, and for clarity, they are not shown in Fig. 3. The anticlinal folds are open in style with limb dips of up to $40^{\circ}$, and thrusting is typically developed on steeper southern limbs (Pharaoh et al. 2016b, 2018). Southward-vergent thrust faulting (Fig. 6a) is revealed by fault plane reflections, most clearly in the massively bedded limestones of the Carboniferous Limestone Supergroup, but also extending into the less reflective zone interpreted as pre-Carboniferous (Caledonian) basement by Pharaoh et al. (2016a, b). The frequent association of anticlinal fold and thrust leads to interpretation of the former as 'ramp anticlines'. Their spatial separation reflects the reactivation of discrete structures within the pre-Carboniferous basement. Northward-vergent anticlinal and thrust structures have been identified in the vicinity of the Anglesey-Quadrant 109 Arch (Fig. 6a), and at the northern end of the Deemster Platform (Fig. 6b). These represent reversal of the original northern marginal fault of the Bowland Basin during inversion. Similar structures are inferred to underlie the Formby Platform and onshore Formby area (Fig. 3), where Namurian reservoirs have leaked into Sherwood (Triassic) and Quaternary strata (Pharaoh et al. 2016b, 2018). The linkage through the intervening East Deemster Basin (Figs. 2, 3) has not yet been demonstrated, but sub-surface mapping is in progress to confirm this. Pharaoh et al. (2016b, 2018) have named this concealed Variscan-age belt of inversion, the Môn- 
Deemster Fold-Thrust Belt, and the similarity of structural style to the Ribblesdale Fold belt along strike, described above, is notable.

On seismic profiles the thrust-faults inferred from steeply inclined zones of reflectivity in the inferred Caledonian basement extend downward until apparently terminated by a zone of strong reflectivity at $>4 \mathrm{~s}$ TWTT. The lack of seismic sections recorded to greater than $6 \mathrm{~s}$ TWTT, and mostly $4 \mathrm{~s}$ TWTT, greatly restricts the precision with which this zone can be mapped, but it appears to be gently inclined to the north or NW (Fig. 6a). Northward-vergent structures associated with Alpine inversion are significant on favourably oriented earlier structures (Figs. 6a, b), as on the Maryport-Lagman Fault System farther north (Chadwick et al. 1993, Pharaoh et al. 2016b, 2018).

\section{Bowland Basin}

\section{a. Onshore}

The past decade represents a period of renewed interest in the Bowland Shale and other midCarboniferous mudstones as they have been identified as potential commercially-viable targets for shale gas and oil (Smith et al. 2010, DECC 2010, Andrews 2013, Hough et al. 2014). During the midCarboniferous, these mudrocks accumulated in a series of linked sub-basins that have been collectively described as the Pennine Basin (Aitkenhead et al. 2002). The Pennine Basin developed across much of present-day northern England, bounded by the Wales-Brabant High in the south and the Southern Uplands in the north (e.g. Waters et al. 2009). Structural platforms and blocks developed locally, and forming numerous sub-basins mapped out within the Pennine basin system.

The Bowland Basin of Ramsbottom (1974) represents the north-western part of the larger Pennine Basin and is broadly equivalent to part of the Craven Basin of Hudson (1933). The basin contains thick sequences of mid-Carboniferous rocks, in places over $4000 \mathrm{~m}$ thick (Arthurton et al. 1988). Within areas of deposition, strata typically comprise a series of interbedded sandstone with mudstone and siltstone. Large variations in thickness developed in response to a proximal or distal setting in relation to sediment supply, the availability of accommodation space within the basin, and changes in sea-level influenced by glacio-eustacy (Brandon et al. 1995).

The Bowland Basin is located between the Askrigg Block and Bowland High to the north, and Clitheroe-Central Lancashire High in the south (Figs. 4a, 5b). It has a surface expression of approximately $25 \mathrm{~km}$ by $55 \mathrm{~km}(1375 \mathrm{sq} \mathrm{km})$, but it extends as a concealed basin farther west, into the Formby area (Figs. 3, 4a), and eastward, into the Harrogate Basin (Figs. 3, 4a, 7). Information regarding the basin comes principally from seismic reflection data, and also from three boreholes recently drilled as part of a shale gas exploration programme (Clarke et al. 2018). The geological evolution of the Bowland Basin is summarised by Lawrence et al. (1987), Gawthorpe (1987), Stephenson et al. (2008) and Clarke et al. (2018).

The basin is a north-easterly trending asymmetrical half-graben that was tectonically active during late Devonian to early Carboniferous times. It formed by the subsidence of a fault block bounded to the north/north-east by the Craven faults (Figs. 3, 4a, 7), active throughout Mississippian time (Hudson 1930, 1944, Arthurton 1984). Local angular unconformity of the Bowland Shales (late BrigantianPendleian) upon Asbian to mid Brigantian limestones, and the Grassington Grit (late PendleianArnsbergian) upon earlier Pendleian strata, has been used as evidence of repeated reactivation of these faults (Arthurton 1984). Westward from Settle the northern boundary of the basin during Mississippian time is speculative. Gravity data suggest the existence of high density rocks (?Lower Palaeozoic) at a 
depth of about $1 \mathrm{~km}$ on a line immediately north of the Sykes and Catlow anticlines (J.D. Cornwell, pers. comm. in Arthurton 1984), the so-called 'Bowland Line' (Fig. 4a). This is supported by the seismic interpretation presented in Fig. 5b. A thick Courceyan section is interpreted to indicate that at least initially, the Bowland Line was the dominant syndepositional basin-controlling fault. In Visean time, the structural polarity of the basin changed, as subsidence shifted to the southern margin of the basin. The south-eastern limit is taken at the present-day Pendle Monocline (Wright et al. 1927, Miller \& Grayson 1982, Aitkenhead et al. 1992), a flexure representing a compressional reactivation (inversion) of the syndepositionally active Pendle Fault System (Arthurton 1984, Fraser \& Gawthorpe, 1990, Kirby et al. 2000). The latter extends for at least $60 \mathrm{~km}$, and perhaps more than $100 \mathrm{~km}$, along the SE margin of the basin. Allowing for Variscan reversal, the original downthrow of the normal fault may have locally exceeded $3000 \mathrm{~m}$ (Kirby et al. 2000). The Mississippian sequence alone thickens from about $2000 \mathrm{~m}$ on the Central Lancashire High, to $4000 \mathrm{~m}$ in the Bowland Basin. South of this structure, Lower Palaeozoic rocks were proved under a thin $(490 \mathrm{~m})$ Mississippian sequence in the Holme Chapel borehole (Fig. 3). Later Namurian strata are now absent from much of the Bowland Basin but it seems probable that $>2000 \mathrm{~m}$ of such strata were deposited there (Earp et al. 1961, Kirby et al. 2000).

Farther west, the Formby Basin, with up to $2400 \mathrm{~m}$ of Permo-Triassic fill (Kirby et al. 2000), overlies the extension of the Bowland Basin to the SW (Figs. 3, 4a). The base of the Carboniferous sequence is poorly constrained, but may lie at a depth $>6000 \mathrm{~m}$. The Pendle Fault System defines the south-eastern edge of the Formby Basin, with up to $4000 \mathrm{~m}$ downthrow of the basement to NW of the fault system. The southern margin of the basin was weakly inverted in latest Dinantian time, when the hangingwall block of the fault system was uplifted (Kirby et al. 2000). Namurian strata onlap onto the fold which resulted. Strong Variscan inversion is indicated by the subcrop of Visean strata beneath the PermoTriassic Unconformity (Fig. 3).

To the NE, beyond the South Craven-Morley Campsall Fault System, the WSW-ENE-trending Harrogate Basin (Figs. 3, 4a, 7) is dextrally offset en échelon from the Bowland Basin by about $15 \mathrm{~km}$. It also contains a relatively thick Mississippian succession, with more than $3000 \mathrm{~m}$ of preserved strata, and basement depths locally exceeding $4000 \mathrm{~m}$ where it passes into the Stainmore Trough (Kirby et al. 2000). These depths are unconstrained by seismic data however. This basin also was a locus for Variscan shortening, and represents the continuation of the Ribblesdale FTB to the NE.

Fraser et al. (1990) classified the Carboniferous strata of northern England into sequences deposited in a number of phases, based on a seismic stratigraphic model, including pre-rift, syn-rift, post-rift and inversion phases. Platform carbonates developed during the early Carboniferous along the northern margin of the Rhenohercynian Ocean (Fraser \& Gawthorpe 2003). Tournaisian strata are absent on the Askrigg Block to north of the North Craven Fault, but crop out in the more deeply eroded anticlines of the fold belt where the Swinden Borehole proved $704 \mathrm{~m}$ of Tournaisian strata (unbottomed). Gravity data suggest that a further $2.3 \mathrm{~km}$ of such strata may overlie Lower Palaeozoic rocks here (J.D. Cornwell, pers.comm. in Arthurton 1984). South of the Pendle Monocline a much thinner Tournaisian sequence was proved in Boulsworth Borehole (Ramsbottom 1974). Crustal extension continued through Visean time, with about $2 \mathrm{~km}$ of Visean subsidence in the central part of the basin, on the northern limb of the Gisburn Anticline. The lowest $500 \mathrm{~m}$ (Chatburn Limestone Group) are carbonate-dominated, but mudstone forms most of the upper part of the sequence (Worston Shale Group, including the Hodder Mudstone Formation). By contrast, the much thinner Visean sequences on the flanks of the basin are carbonate-dominated throughout. This syn-rift phase (the north England extensional province of Fraser \& Gawthorpe 2003), allowed the lower part of the Bowland Shale (cf. Waters et al. 2009) to accumulate. During Brigantian time, the Bowland Shale was deposited as a transgressive systems tract (de Pater \& Baisch 2011) which at this time is thought to have been fringed by reefs. This influenced sediment 
supply, with a hiatus in sedimentation proposed at periods of high-stand, debrites prograding into the basin (Newport et al. 2017) and the development of sandbodies (e.g. the locally-developed Pendleside Sandstone) during times of lowstand. In deeper parts of the basin, the sediment-water interface was anoxic, allowing for the accumulation of organic-rich mudrocks (Kirby et al. 2000).

By Pendleian time, the basin entered a phase of thermal sag (Leeder 1982), during which the upper part of the Bowland Shale was deposited. Namurian strata are about $2 \mathrm{~km}$ thick in the Pendle Monocline, and about $1400 \mathrm{~m}$ thick in Holme Chapel Borehole (Fig. 3). Minor episodes of structural deformation continued through Pendleian to Moscovian time (Kirby et al. 2000), ensuring local thickness variations in the upper part of the Bowland Shale and overlying Millstone Grit across much of the Pennine Basin. Conglomeratic carbonate rocks within the Carboniferous succession attest to the likelihood of structural activity during the mid-Carboniferous, which may have resulted in the development of local topographic relief in the basin (Aitkenhead et al. 1992). Cyclic sedimentation within the Bowland Shale is strongly influenced by periods of subsidence, resulting in the development of 'Marine Band' intervals when water depths were greatest. These intervals commonly occur across numerous sub-basins within the Pennine Basin, with the preservation of age-diagnostic ammonoid fauna allowing the correlation of age-equivalent sedimentary units to be made possible. An interval of major uplift occurred during the late Carboniferous (Silesian), when significant parts of the Carboniferous succession were eroded (Arthurton et al. 1988).

Other relevant onshore basins to mention are the small Carboniferous basins associated with the Menai Strait Fault System (Gibbons 1987) in Anglesey and North Wales (Figs. 1, 2, 3, 7 and 9). The southernmost of these, forming the Little Orme, near Llandudno, lies in the footwall of the Aber-Dinlle Fault (Fig. 8). The Gloddaeth Syncline contains a reduced succession, with Asbian carbonates unconformably overlain by Westphalian B strata, representing a gap of about 25 Ma (Needham \& Morgan 1997). The Great Orme Syncline, lying in the hangingwall of the same fault, to the north, contains a thicker Asbian and Brigantian sequence. The hangingwall of the Dinorwic Fault in the Menai Strait itself contains strata of the Warwickshire Group (Asturian/Westphalian D) unconformable on Asbian-Brigantian carbonates (Fig. 9). In the hangingwall of the Berw Fault in the Malltraeth area (Fig. 9), the half-graben hosting the Anglesey Coalfield contains $150 \mathrm{~m}$ of Namurian strata, overlain by 330 $\mathrm{m}$ of Pennine Coal Measures Group strata (Langsettian/Westphalian A) and finally, $100 \mathrm{~m}$ of Warwickshire Group strata (Davies et al. 2011). A full Namurian sequence is only found offshore (Jackson \& Mulholland 1993; Pharaoh et al. 2016b). Sinistral displacement of $1.5 \mathrm{~km}$ across the Berw Fault has been inferred from displaced Palaeocene dykes (Bevins et al. 1996).

\section{b. Offshore extension of the Bowland Basin}

As described above, the limited borehole penetrations through the late Palaeozoic section limit the detail with which the offshore extension of the Bowland Basin, referred to as the Môn-Deemster Basin by Pharaoh et al. (2018), is known. Interpretation of regional seismic lines indicates that the Quadrant 109 Arch (Figs. 2, 3) represents the inverted southern edge of a Mississippian carbonate ramp developed in the Eubonia Tilt-block (Pharaoh et al. 2016; 2018). The Bowland Basin is restricted to the south side of the arch. The deepest penetration, by well 110/7b-6, drilled by Kelt in 1988, was drilled on the inversion anticline with greatest amplitude on the northern margin of the basin, just south of the bounding fault (Fig. 3). This mildly deviated well penetrated $450 \mathrm{~m}$ of Upper Bowland Shale (Arnsbergian). This indicates that comparable thicknesses of Bowland Shale are present offshore to those of the onshore basin. The Carboniferous sequence also thins towards the Menai Strait Fault System near the coast of North Wales. Here, boreholes show that the Namurian sequence has been attenuated or excised beneath Pennine Coal Measures Group strata, and late Carboniferous strata of the 
Warwickshire Group may be present (Figs. 2, 3) (Pharaoh et al. 2016b, 2018). The southern margin of the basin is defined by a SSW-ENE trending en échelon array of normal faults (Fig. 7) with northerly downthrows. Some of these are exposed onshore and have been mapped and described previously as components of the Menai Strait Fault System (MSFS) e.g. the Berw, Dinorwic and Aber-Dinlle faults (Gibbons 1987, Needham \& Morgan 1997), and delimit the Carboniferous basins on Anglesey and the Great Orme described above (Fig. 7). Other examples suffered minor or no reactivation in Permian to Jurassic time and lie concealed beneath the post-Carboniferous cover in Liverpool Bay. The en échelon array of the MSFS is left-stepping, reflecting sinistral transtension during early Carboniferous time. The fault system probably originated earlier however, either during Ordovician extension or subsequent Acadian compression. The faults apparently define the northern limit of Warwickshire Group (latest Carboniferous) strata (Fig. 3), indicating likely reversal during Variscan inversion. The extensional faults extend down to, but do not penetrate, an intra-basement detachment surface (see section 3) dipping gently northward beneath the basin.

The inferred depositional geometry of the Bowland Basin is that of a half-graben, dominated by a major syndepositional system of controlling faults on the northern margin of the basin, adjacent to the Quadrant 109 Arch (e.g. Fig, 6a). The offshore extension of the basin is therefore inferred to have a vergence comparable to that of the Eubonia Tilt-block north of the Quadrant 109 Arch (Pharaoh et al. 2018), with the greatest subsidence (and accumulated thickness of the prolific Bowland Shale source rock) inferred on the northern margin of the basins. This extensional geometry most readily explains the increased amplitude of the inversion anticline along the northern margin.

\section{Ganderian basement substrate}

In southern Britain, key elements of the Caledonian Orogen are best preserved in a composite Late Neoproterozoic basement - Lower Palaeozoic cover assemblage that crops out in Anglesey and in the Llŷn Peninsula of North Wales (Figs. 1, 2, 3, 9), forming part of the composite margin of Gondwana (e.g. van Staal et al. 1998, Waldron et al. 2011, 2014, 2018). Anglesey (Ynys Môn) is arguably one of the most geologically complicated regions of the southern UK and spans an orogen-scale eventframework that includes:

1) cessation of Neoproterozoic subduction in the Pacific-like, peri-Pannotian ocean referred to as Panthalassa,

2) dispersal of Laurentia and the Iapetus rift-drift phase in Cambrian time,

3) subduction-driven accretionary tectonics during a short-lived Penobscot Orogeny in early Ordovician time (Schofield et al., 2008),

4) post-Penobscot (mid to late Ordovician) volcanism, subsidence and deposition preceding (Salinic) terminal collision with Laurentia in late Silurian time,

5) Acadian post-collisional development and Rheic Ocean accretion in early Devonian time.

One particularly distinctive tectonic unit in Anglesey, first recognised by Greenly (1919) a century ago, is the Penmynydd Zone (Gibbons, 1983). This is a megashear zone (Fig. 10) comprising highly sheared components derived from both Ganderian hangingwall (Mona Complex, blueschists) and the Gondwanan footwall. Its age of formation is not well constrained, but probably encompasses at least the first two events of the framework outlined above. The presence of protoliths with a wide range of densities, from felsic lavas and cogenetic granites, to blueschist and amphibolite (Gibbons, 1983), is likely to enhance the reflectivity of the zone. Another key element is the Carmel Head Thrust (Figs. 9, 10) of northern Anglesey, a Caledonian structure postdating deposition of the Silurian sequence, and thus of Acadian (early Devonian) age. 
Further crustal elements of comparable age may be exposed in the Craven Pennine inliers of Northern England (Figs. 2, 3, 4a). The stratigraphy and structure of the Ingleton Group has been comprehensively reviewed by Soper \& Dunning (2005). A poorly dated sequence of rather massive deep water turbidite strata were isoclinally folded and cleaved prior to deposition of late Ordovician and Silurian strata of the Windermere Supergroup (Leedal \& Walker 1950, Johnson 2000). Given the uncertainties in dating, the simplest interpretation is that the Ingleton Group strata were also deformed during the Penobscotian Phase (Pharaoh 2018). Thus the belt of Penobscotian deformation likely extends from the Irish Sea Horst (Anglesey) beneath the eastern Irish Sea to the Pennine inliers (Fig. 1).

On seismic profiles in the offshore region (e.g. Fig. 6a), the thrust-faults inferred from steeply inclined zones of reflectivity in the inferred Caledonian basement extend downward until apparently terminated by a zone of strong reflectivity over an interval of about 1s TWTT thick (equivalent to about $3 \mathrm{~km}$ ). The lack of seismic sections recorded to greater than $6 \mathrm{~s}$ TWTT, and mostly $4 \mathrm{~s}$ TWTT, greatly restricts the precision with which this zone can be mapped, but it appears to be gently inclined to the north or NW (Fig. 6a). A similar zone of strong reflectivity is observed on BIRPS profiles (Fig. 11) west of Anglesey (Brewer et al. 1983, Bois et al. 1990, Bois 1991, Klemperer \& Hobbs 1991) identified as the South Irish Sea Lineament. The latter is an inferred reactivated Caledonian thrust and terrane boundary, correlated with the Menai Strait Fault System (Gibbons 1987) onshore.

Air gun trials for the South-West Approaches Traverse (SWAT) profiles (SWAT-0 and SWAT-0A) were located on a segment of the WINCH-4 profile ( $\mathrm{km} \mathrm{80-100)} \mathrm{with} \mathrm{enhanced} \mathrm{mid-crustal} \mathrm{reflectivity}$ (Warner 1986). Navigational errors between these lines were less than $100 \mathrm{~m}$ (Klemperer \& Hobbs 1991). Both image the South Irish Sea Lineament dipping northward across the sections from 2.5 to 5.0 s TWTT, equivalent to a dip of about $18^{\circ}$ (Chadwick et al. 1996). All three lines show a zone of enhanced reflectivity over a vertical zone of about $1 \mathrm{~s}$ TWTT (Fig. 11). Fig. 9 incorporates the mapping (in TWTT) of the upper surface of this zone through the BIRPS and available commercial datasets. The interpretation preferred here is that the zone represents an intra-crustal 'megashear zone' about $3 \mathrm{~km}$ thick, correlative with the Penmynydd Zone exposed along the coast of the Menai Strait. The lower boundary of the megashear zone is correlated with the Llŷn Shear Zone exposed onshore (Fig. 11), while its upper boundary is most conveniently taken at the Berw Shear Zone, exposed in southern Anglesey. The zone offshore likely comprises the same range of sheared rock types as in Anglesey and Llŷn. The Penmynydd Zone forms the regional detachment for extensional faulting of Carboniferous and Permian-Jurassic age in the Central Irish Sea Basin (Fig. 11). Unfortunately, deep seismic reflection data are not available east of Anglesey, beneath the East Irish Sea Basin. Similar ramp-flat acoustic geometries on the accessible, largely speculative seismic data in this area, suggest the overlying sedimentary basins are having a velocity pull-down effect on the apparent geometry of the zone. A SSW-NNE trending belt of thickening of the Penmynydd Zone is inferred to reflect southward-directed imbrication by a post-Penobscotian, pre-Carboniferous structure (Fig. 6a), here correlated with the Acadian Carmel Head Thrust. Regional mapping indicates that the south-dipping normal fault defining the northern boundary of the Bowland Basin to NE of Anglesey, developed by extensional reactivation of the crust in the hangingwall of this Acadian-age structure (Fig. 6a).

\section{Section balancing and restoration}

The seismic interpretations of the transects located on Figs. 3 and 7 have been analysed using 2D MOVE software for section balancing (CMidland Valley Associates). On the left hand side 
of the diagram (Fig. 12), the present day situation is depicted; on the right hand side, levelled to the base of the Cumbrian Coast Group, the pre-Permian disposition is shown.

Transect A (the westernmost offshore profile, located about $15 \mathrm{~km}$ to east of Anglesey, Fig. 3) demonstrates major asymmetry of the Bowland Basin graben structure, resulting from early Carboniferous extensional reactivation of the crust in the hangingwall of the Carmel Head Thrust (CHT). About 20\% Mississippian extension is observed across the basin. Most of the 5\% Variscan shortening observed is focussed at the northern basin margin. Numerous late Pennsylvanian-prePermian extensional faults reflect late Variscan extensional collapse of the inversion structure. Significant shortening of the Conwy Platform in the south appears to have been caused by Alpine deformation.

Transect B, located $25 \mathrm{~km}$ east of Transect A, is based on an interpreted seismic section previously presented by Pharaoh et al. (2018, Fig. 3). Here the boundaries of the basin are less sharply defined and the position of the northern marginal fault is unclear. The Carmel Head Thrust cannot be identified with certainty, although the southward-vergent Variscan thrust and anticline pairs imaged by the seismic data may be localised in the hangingwall of comparable Acadian-age structures with the same vergence. Evidence for Mississippian extension is also less clear, the percentage of extension (5\%) observed is less than on Transect A, and the shortening somewhat greater (c. 12\%).

Transect C, the easternmost offshore profile, is located $20 \mathrm{~km}$ east of transect B, and demonstrates the presence of a major northward-vergent Variscan structure at the northern edge of the Deemster Platform. This is a compressional reactivation of a Mississippian extensional fault. Observed Mississippian extension is about $15 \%$ across the basin, and one major late Pennsylvanian extensional fault is present. The relationship to deeper basement structure is obscure. The majority of the Variscan shortening (about 12\%) is focussed at the northern margin of the basin. The folding of the PermoTriassic cover and the Top 'Platy Illite Zone' Reflector (Fig. 6b) indicate that a significant component of Alpine inversion is also involved here.

Transect D is located onshore between 20 and $35 \mathrm{~km}$ east of transect C, and oblique to it (Fig. 3). The presence of a more or less continuous Permo-Triassic cover sequence in the Formby and Fylde basins allows a more complete evaluation of the extensional and contractional history of the onshore part of the basin than farther east, where the cover is missing. Significant late Pennsylvanian/pre-Permian extensional faulting is observed at the northern end of the section. However, the strongly oblique orientation of the transect (UKOGL regional line RG-006) and uncertainty about the position of marginal faults so complicates determination of extension/contraction values that the latter are considered unreliable.

Transect E is located onshore within the Bowland Basin crop (Figs. 3, 4a). Erosion of the PermoTriassic cover and significant amount of Carboniferous section down to the late Visean level leads to poorly constrained values of extension and contraction. Within these caveats, Mississippian extension across the narrow basin here seems to have been significant, perhaps as much as $50 \%$. This value is strongly dependent on the geometry of the bounding faults, which are poorly imaged by seismic data with relatively short record lengths. Variscan shortening is of the order of $20 \%$. 


\section{Discussion}

The length of the FTB between Anglesey and the Craven inliers is a minimum of $165 \mathrm{~km}$. Regional considerations suggest that it extends towards the Flamborough Head Fault Zone (Figs. 1, 3, 4a, 7), via the Harrogate Basin (Kirby et al. 2000). This zone was favoured by Woodcock \& Strachan (2012) as the most likely terrane boundary between Avalonia and the Leinster-Lakesman (Ganderia) Terrane. Here the structure of the basement may be dominated by a SW-NE trending zone of strong Acadian (early Devonian) deformation paralleling the inferred boundary between Avalonia and Laurentia (the Iapetus Suture). There is no strong evidence that the Penobscotian terrane boundary also follows this course, as in the Irish Sea region. In the Craven Inliers of the Pennines, the evidence from the Ingleton Group at crop is that the early (?Penobscotian, ?early Ordovician) cleavage has a WNW-ESE trend (Soper \& Dunning, 2005), although this might be a local deviation resulting from crustal inflation at the margin of the nearby concealed Wensleydale Granite. The seismic evidence reviewed here confirms the weak mechanical nature of this crustal suture zone, located between more rigid massifs to south (Anglo-Brabant Massif) and north (Lake District-North Pennine massifs). Reactivation of this mechanically weak crust during Mississippian extension and subsequent Variscan compression resulted in strongly focussed deformation. Further shortening on selected structures occurred during the Alpine Orogeny in Cenozoic time.

\section{Conclusions}

The rather complex structural evolution outlined above is summarised in Fig. 13. Carboniferous strata underlying the southern part of the Permo-Mesozoic East Irish Sea Basin form the westward continuation of the onshore Bowland Basin. The concealed Môn-Deemster FTB offshore, a Variscan inversion belt, is apparently contiguous with, and comparable in structural style, to the Ribblesdale FTB onshore. Balanced sections indicate about 5-8\% shortening throughout the FTB, while the presence of en échelon and positive flower geometries indicates a component of transpression. Offshore, Variscan anticline-thrust pairs are dominantly southward-vergent, except at the northern margin of the FTB. These structures represent compressional reactivations within the hangingwalls of Mississippian extensional faults.

The principal syndepositional controlling faults (and depocentre) of the offshore Bowland Basin lay on the northern side of the basin, adjacent to the Quadrant 109 Arch north of Anglesey, and the northern edge of the Deemster Platform, where there is evidence of further modification resulting from Alpine reactivation. In the west, the northern marginal fault is developed in the hangingwall of a southwardvergent basement fault, correlated with the Acadian Carmel Head Thrust onshore. Along the Conwy coast of North Wales, and passing through Liverpool Bay, an en échelon array of Carboniferous transtensional faults controls the ramp at the southern margin of the basin, where further Alpine inversion is observed. The Carboniferous sequence becomes attenuated through these basins and is very incomplete by the time the mainland is reached. These faults include elements of the Menai Strait Fault System, such as the Berw, Dinorwic and Aber-Dinlle faults. The orientation of the latter, significantly oblique to the assumed N-S Carboniferous extension direction, suggests that these represent extensional reactivations of Acadian thrusts. The Carboniferous faults were only locally reactivated by W-E directed Triassic extension, most notably the Berw Fault (BGS 1994).

All of the Carboniferous extensional faults, and most of the Acadian compressional faults, appear to terminate above a northward-dipping zone of enhanced intra-crustal reflectivity about $3 \mathrm{~km}$ thick, 
interpreted as the regional detachment. The latter is correlated with the Penmynydd Zone locally exposed on the Menai coast of North Wales, a heterolithic 'megashear zone' of pre-Acadian age. This Ganderian substrate likely extends from Anglesey to Ingleton (and beyond?). Apparent imbrication of the zone by the Carmel Head Thrust confirms that the latter is a particularly significant Acadian structure. Its offshore extension can be mapped up to $20 \mathrm{~km}$ east of Anglesey. The Menai Strait Fault System is not a terrane boundary, but reflects late, relatively brittle exhumation of the crust, including the Penmynydd Zone. The persistent weakness of the belt of crust located between more rigid massifs to north and south, has been the dominant mechanical control on the evolution of the late Mississippian Bowland Basin and its Variscan inversion, the Môn-Deemster-Ribblesdale FTB. Subsequently, Alpine inversion of the overlying Permo-Mesozoic East Irish Sea Basin (not depicted in Fig. 13) was focussed on reactivated older structures. In this context, the preservation of Anglesey as the most significant outcrop of the Irish Sea Landmass, is remarkable, and may reflect some special circumstance of either the Variscan or Alpine inversions.

\section{Acknowledgements}

This work was initiated within a joint-industry project for the former Department of Energy and Climate Change (DECC) now Oil and Gas Authority (OGA), Oil and Gas UK, and 49 oil and gas company sponsors as part of the 21CXRM ( $21^{\text {st }}$ Century Exploration Roadmap) Palaeozoic Project. Provision of seismic data by IHS Global Limited and CDA (offshore) and UKOGL (onshore) is gratefully acknowledged. Some of the diagrams were drawn by Ian Longhurst. Reviews by Dave McCarthy (BGS internal reviewer), Nigel Woodcock and an anonymous reviewer improved the manuscript. This paper is published with the approval of Executive Director, BGS (UKRI).

\section{References}

AITKENHEAD, N., McC BRIDGE, D., RILEY, N. J. \& KIMBELL, S.F. 1992. Geology of the country around Garstang. Memoir of the British Geological Survey, Sheet 67 (England and Wales).

AITKENHEAD, N., BARCLAY, W.J., BRANDON, A., CHADWICK, R.A., CHISHOLM, J.I., COOPER, A.H., \& JOHNSON, E.W. 2002. British regional geology: the Pennines and adjacent areas. Fourth edition. (Keyworth, Nottingham: British Geological Survey).

ANDREWS, I. J. 2013. The Carboniferous Bowland Shale gas study: geology and resource estimation. British Geological Survey for Department of Energy and Climate Change, London, UK.

ARTHURTON, R.S. 1984. The Ribblesdale fold belt, N W England - a Dinantian - early Namurian dextral shear zone. 131-138. In: HUTTON, D.H.W., \& SANDERSON, D.J. (eds.) Variscan tectonics of the North Atlantic region. Geological Society, London, Special Publications 14, 270pp.

ARTHURTON, R.S., JOHNSON, E.W., \& MUNDY, D.J.C. 1988. Geology of the country around Settle. Memoir of the British Geological Survey, Sheet 60 (England and Wales).

BARRETT, P.A. 1988. Early Carboniferous of the Solway Basin: A tectonostratigraphic model and its bearing on hydrocarbon potential. Marine and Petroleum Geology 5, 271-281. 
BEVINS, R.E., HORAK, J.M., EVANS, A.D., \& MORGAN, R. 1996. Palaeogene dyke swarm, N W Wales: evidence for Cenozoic sinistral fault movement. Journal of the Geological Society, London 153, $177-180$.

BOIS, C., LEFORT, J.-P., LE GALl, B., SIBUET, J.-C., GARIEL, O., PINET, B., \& CAZES, M. 1990a. Superimposed Variscan, Caledonian and Proterozoic features inferred from deep seismic profiles recorded between southern Ireland, southwestern Britain and western France. Tectonophysics 177, 1537.

BOIS, C., LEFORT, J.-P., LE GALL, B., SIBUET, J.-C., GARIEL, O., PINET, B., \& CAZES, M. 1990b. Traces of Caledonian and Proterozoic crustal features in deep seismic profiles between France and the British Isles. Tectonophysics 185, 21-36.

BOIS, C. 1991. Geological significance of seismic reflections in collision belts. Geophysical Journal International 105, 55-69.

BRANDON, A., AITKENHEAD, N., CROFTS, R.G., ELLISON, R.A., EVANS, D.J. \& RILEY, N.J. 1998. Geology of the country around Lancaster. Memoir for 1:50 000 Geological, Sheet 59 (England and Wales).

BRANDON, A., RILEY, N.J., WILSON, A.A. \& ELLISON, R.A. 1995. Three early Namurian (E1c E2a) marine bands in central and northern England, UK, and their bearing on correlations with the Askrigg Block. Proceedings of the Yorkshire Geological Society 50, 333 - 355.

BREWER, J.A., MATTHEWS, D.H., WARNER, M.R., HALl, J., SMYTHE, D.K., \& WHITTINGTON, R.J. 1983. BIRPS deep seismic reflection studies of the British Caledonides. Nature 305, 206-210.

BRITISH GEOLOGICAL SURVEY (BGS). 1994. East Irish Sea. Special Sheet Edition. Solid Geology.1:250 000. (Edinburgh, Scotland: British Geological Survey)

BRITISH GEOLOGICAL SURVEY (BGS). 2009. St George's Channel. Special Sheet Edition. Bedrock Geology.1:250 000. (Edinburgh, Scotland: British Geological Survey)

Bushell, T. P. 1986. Reservoir geology of the Morecambe Field. In: BrooKs, J., GoFF, J. C. \& VAN HOORN, B. (eds.). Habitat of Palaeozoic gas in NW Europe. Geological Society, London, Special Publications, 23, 189-208.

BUTLER, M., \& JAMIESON, R. 2013. Preliminary interpretation of six regional seismic profiles across onshore basins of England. UK Onshore Geophysical Library.

Chadwick, R. A., Evans, D. J. \& Holliday, D. W. 1993. The Maryport Fault: the post-Caledonian tectonic history of southern Britain in microcosm. Journal of the Geological Society, London 150, 247-250.

CHADWICK, R. A., \& PHARAOH, T.C. 1996. Seismotectonics of the UK. Final Report. Main Text plus appendices A, B and D. BGS Technical Report WA/96/3C: Issue 1.0. 54 pp plus Figures and 96 Enclosures. Prepared in confidence for Nuclear Electric PLC. 
ClARKE, H., TURNER, P., BUSTIN, R.M., RILEY, N.J., \& BESLY, B. 2018. Shale gas resources of the Bowland Basin, N W England: a holistic study. Petroleum Geoscience.

http://dx.doi.org/10.1144/petgeo2017-066

Corfield, S.M., GAWTHORPe, R.L., GAGE, M., Fraser, A.J. \& Besly, B.M. 1996. Inversion tectonics of the Variscan foreland of the British Isles. Journal of the Geological Society, London 153, 17-32.

DAVIES, J.R., SOMERVILLE, I.D., WATERS, C.N., \& JONES, N.S. 2011. North Wales. Chapter 8 In: WATERS, C.N., SOMERVILLE, I., et al. (eds.). A Revised Correlation of Carboniferous Rocks in the British Isles. Special Report 26. Geological Society, London.

DECC. 2010. The unconventional hydrocarbon resources of Britain's onshore basins - shale gas. Department of Energy \& Climate Change, London, UK.

de PATER, C.J. \& BAISCH, S. 2011. Geomechanical study of Bowland Shale Seismicity synthesis report. Report by StrataGen-Q-con for Cuadrilla Resources Ltd.

https://www.scribd.com/document/95322131/Geomechanical-Study-of-Bowland-Shale-Seismicity. $19^{\text {th }}$ March 2018.

EARP, J.R., MAGRAW, D., POOLE, E.G., LAND, D.H., \& WHITEMAN, A.J. 1961. Geology of the country around Clitheroe and Nelson. Memoir of the Geological Survey, Sheet 68 (England and Wales).

FRASER A J. \& GAWTHORPE, R.L. 2003. An atlas of Carboniferous basin evolution in northern England. Geological Society, London, Memoir 28.

FRASER A.J., NASH, D.F., STEELE, R.P. \& EBDON, C.C. 1990. A regional assessment of the intraCarboniferous play of northern England. In: BROOKS, J. (ed.). Classic Petroleum Provinces. Geological Society, London, Special Publications 50, 417-440.

GAWTHORPE, R.L. 1987. Tectono-sedimentary evolution of the Bowland Basin, N England, during the Dinantian. Journal of the Geological Society, London 144, 59-71.

GENT. C. M. A. 2016. Maturity modelling of well 110/07b-6. British Geological Survey Commissioned Report, CR/16/043.

GEOCHEM LABORATORIES LIMITED, 1988. Prepared for Kelt UK Ltd, London. Geochemical Evaluation and Correlation Study Morecambe Bay 110/7b-6 Well. (110_07b_6_rep_GEOL_CHEM_105249616.pdf released on CDA).

GIBBONS, W.A. 1983. The Monian Penmynydd zone of metamorphism in Llŷn, North Wales. Geological Journal 18, 1-21.

GIBBONS, W.A. 1987. Menai Strait fault system: an early Caledonian terrane boundary in North Wales. Geology 15, 744-747.

GIBBONS, W.A., \& HORÁK, J.M. 1996. The evolution of the Neoproterozoic Avalonian subduction system: Evidence from the British Isles. In: NANCE, R.D., THOMPSON, M.D. (eds.) 1996. Avalonian and Related Peri-Gondwana Terranes of the Circum-Atlantic. Geological Society of America Special Paper 304, 269-280. 
GRADSTEIN, F.M., OGG, J.G., SCHMITZ, M., \& OGG, C. 2012. The Geologic Time Scale. Elsevier and the Geologic TimeScale Foundation website: https://engineering.purdue.edu/stratigraphy.

GREENLY, E. 1919. The Geology of Anglesey. Memoir of the Geological Survey of Great Britain, Sheet 78, 980pp. (2 volumes).

HORÁK, J.M., \& GIBBONS, W.A. 2000. Introduction. Anglesey and the Lleyn Peninsula (Llŷn). In: CARNEY, J.A., et al. Precambrian Rocks in England and Wales. p145-148. Geological Conservation Review 20, Joint Nature Conservation Committee, Peterborough.

Hough, E., VANE, C.H., SMITH, N.J.P. \& MOSS-HAYES, V. 2014. The Bowland Shale in the Roosecote Borehole of the Lancaster Fells sub-basin, Craven Basin, UK: a potential UK shale gas play? SPE paper 167696.

HUDSON, R.G.S. 1930. The Carboniferous of the Craven reef belt, the Namturian unconformity at Scaleber, near Settle. Proceedings of the Geologists' Association 41, 290-322.

HUDSON, R.G.S. 1933. The scenery and geology of north-west Yorkshire. Proceedings of the Geologists' Association 44, 227-269.

HUDSON, R.G.S. 1944. A pre-Namurian fault scarp at Malham. Proceedings of the Leeds Philosophical and Literary Society 4, 226-232.

HUDSON, R.G.S. \& MITCHELL, G.H. 1937. The Carboniferous geology of the Skipton Anticline. Summary of progress of the Geological Survey of Great Britain for 1935, 1-45. (London: HMSO).

JACKSON, D.I., JACKSON, A.A., EvAns, D., WINGFIELD, R.T.R., BARNES, R.P. \& ARTHUR, M.J. 1995. United Kingdom offshore regional report: the geology of the Irish Sea. (London: HMSO).

JACKSON, D.I., JONES, N.S., \& WATERS, C.N. 2011. Chapter 16: Irish Sea (including Kish Bank). In: Waters, C.N., SOMERVIlle, I.D., Jones, N.S., Cleal, C.J., Collinson, J.D., Waters, R.A., Besly, B.M., DeAn, M.T., STEPHENSON, M.H., DAVIES, J.R., Freshney, E.C., JACKSON, D.I., Mitchell, W.I., Powell, J.H., BARClaY, W.J., Browne, M.A.E., LeVERIDGE, B.E., LONG, S.L., \& MCLEAN, D. (eds). A Revised Correlation of Carboniferous Rocks in the British Isles. Geological Society, London, Special Reports, 26, 110-116.

JACKSON, D.I., MUlholland, P., JONES, S.M. \&WARRINGTON, G. 1987. The geological framework of the East Irish Sea Basin. In: Brooks J. \& GLENNIE, K. (ed.) Petroleum Geology of North West Europe, 191-203 (London: Graham and Trotman).

JOHNSON, E.W. 2000. Thornton and Twisleton Glens. P208-212. In: CARNEY, J.A., et al. Precambrian Rocks in England and Wales. Geological Conservation Review 20, Joint Nature Conservation Committee, Peterborough.

Kirby, G. A., Baily, H. E., Chadwick, R. A., Evans, D. J., Holliday, D. W., Holloway, S., Hulbert, A. G., Pharaoh, T. C., Smith, N. J. P., AitKenhead, N. \& Birch, B. 2000. The structure and evolution of the Craven Basin and adjacent areas. Subsurface Memoir of the British Geological Survey. (Keyworth, Nottingham: British Geological Survey.) 130pp. 
KLEMPERER, S., \& HOBBS, R. 1991. The BIRPS Atlas. Deep seismic reflection profiles around the British Isles. Cambridge University Press, Cambridge.

LAWRENCE, S.R., COSTER, P.W. \& IRELAND, R.J.1987. Structural development and petroleum potential of the northern flanks of the Bowland Basin (Carboniferous), North west England. p225-232 In: BROOKS, J. and GLENNIE, K. (eds) Petroleum Geology of north-west Europe, (London: Graham \& Trotman).

LEEDAL, G.P., \& WALKER, G.P.L., 1950. A restudy of the Ingletonian of Yorkshire. Geological Magazine 87, 57-66.

LEEDER, M R. 1982. Upper Palaeozoic basins of the British Isles - Caledonide inheritance versus Hercynian plate margin processes. Journal of the Geological Society, London 139, 479-491.

MATLEY, C.A. 1928. The Precambrian Complex and associated rocks of SW Lleyn (Carnarvonshire). Quarterly Journal of the Geological Society, London 84, 440-454.

MILLER, J. \& GRAYSON, R.F. 1982. The regional context of Waulsortian facies in northern England. In: BOLTON, K., LANE, R.H., \& LE MONE, D.V. (eds.). Symposium on the Palaeoenvironmental Setting and Distribution of the Waulsortian Facies. p17-33. El Paso Geological Society and the University of Texas at El Paso.

MOSELEY, F. 1956. The geology of the Keasden area, west of Settle, Yorkshire. Proceedings of the Yorkshire Geological Society 30, 331-352.

MOSELEY, F. 1972. A tectonic history of north-west England. Journal of the Geological Society, London 128, 561-598.

MUIR, M.D., BLISS, G.M., GRANT, P.R., \& FISHER, M.J., 1979. Palaeontological evidence for the age of some supposedly Precambrian rocks in Anglesey, North Wales. Journal of the Geological Society, London 136, 61-64.

NEEDHAM, T., \& MORGAN, R. 1997. The East Irish Sea and adjacent basins: new faults or old? Journal of the Geological Society, London 154, 145-150.

NEWPORT, S. M., JERRETT, R. M., TAYLOR, K. G., HOUGH, E. \& WORDEN, R.H. 2017.

Sedimentology and microfacies of mud-rich slope successions: the Carboniferous Bowland Basin, NW England (UK). Journal of the Geological Society, London 175, 247 -262.

PEDDY, C., BROWN, L.D., \& KLEMPERER, S.L., 1986. Interpreting the deep structure of rifts with synthetic seismic sections. In: BARAZANGI, M., BROWN, L. (eds.). Reflection Seismology: A Global Perspective. American Geophysical Union Geodynamic Series 13, 301-311.

PHARAOH, T.C. 2018. The Anglo-Brabant Massif: persistent but enigmatic palaeo-relief at the heart of western Europe. In: LEE, J. \& WOODS, M.A. (eds). Geology of England. Proceedings of the Geologists' Association. 
PharaOH, T.C., KIRK, K., QuinN, M., SANKey, M. \& Monaghan, A.A. 2016a. Seismic Interpretation and generation of depth surfaces for late Palaeozoic strata in the Irish Sea Region. British Geological Survey Commissioned Report, CR/16/041. 65pp.

PharaOh, T.C., Smith, N.J.P., KirK, K., Kimbell, G.S., Gent, C., Quinn, M., \& Monaghan, A.A. 2016b. Palaeozoic Petroleum Systems of the Irish Sea. British Geological Survey Commissioned Report, CR/16/045. 135pp.

PHARAOH, T.C., GENT, C.M.A., HANNIS, S.D., KIRK, K.L., MONAGHAN, A.A., QUINN, M.F., SMITH, N.J.P., VANE, C.H., WAKEFIELD, O., \& WATERS, C.N. 2018. An overlooked play: Structure, stratigraphy and hydrocarbon prospectivity of the Carboniferous in the East Irish Sea - North Channel Basin. In: MONAGHAN, A.A., UNDERHILl, J.R., MARShAll, J.E.A. \& HEWETT, A. (eds.). Palaeozoic Plays of NW Europe. Special Publication 471, Geological Society of London. https://doi.org/10.1144/SP471.7

PHILLIPS, J. 1836. Illustrations of the Geology of Yorkshire, Part II. The Mountain Limestone District. Murray, London. xx +253 pp.

RAMSBOTTOM, W.H.C. 1974. Dinantian. In: RAYNER, D.H., HEMINGWAY, J.E. (eds.). The Geology and Mineral Resources of Yorkshire. Yorkshire Geological Society.

PLAYFAIR, J. 1802. Illustrations of the Huttonian Theory of the Earth (London: Cadell \& Davies; Edinburgh: William Creech).

REEDMAN, A.J., LEVERIDGE, B.E., EVANS, R.B. 1984. The Arfon Group ('Arvonian') of North Wales. Proceedings of the Geologists' Association 95, 313-321.

SCHOFIELD, D.I., EVANS, J.A., MILLAR, I.L., WILBY, P., ASPDEN, J.A. 2008. New U-Pb and RbSr constraints on pre-Acadian tectonism in North Wales. Journal of the Geological Society, London 165, 891-894.

SCHOFIELD, D.I., POTTER, J., BARR, S.M., HoRÁK, J.M., MiLlAR, I.L. \& LONGSTAFFE, F.J. 2016. Reappraising the Neoproterozoic 'East Avalonian' terranes of southern Great Britain. Gondwana Research 35, 257-271.

SHACKLETON, R.M. 1975. Precambrian rocks of North Wales. In: HARRIS et al. (eds.). A Correlation of the Precambrian Rocks in the British Isles. Geological Society, London, Special Report 6, 76-82.

SMITH, N.J.P., TURNER, P. \& WILLIAMS, G. 2010. UK data and analysis for shale gas prospectivity. In: VINING, BA \& PICKERING, SC (eds.). Petroleum Geology: from Mature Basins to New Frontiers Proceedings of the $7^{\text {th }}$ Petroleum Geology Conference. Geological Society of London, $1087-1098$.

SOPER, N.J. \& DUNNING, F.W. 2005. Structure and sequence of the Ingleton Group, basement to the central Pennines of northern England. Proceedings of the Yorkshire Geological Society 55, 241-261. 
STEPHEnSON, M.H., MILlWARD, D., LENG, M.J. \& VANE, C.H. 2008. Palaeoecological and possible evolutionary effects of early Namurian (Serpukhovoan, Carboniferous) glacioeustatic cyclicity. Journal of the Geological Society, London 165, 993 - 1005.

SUESS, E. 1904. The Face of the Earth. Clarendon Press, Oxford.

TIEZSCH-TYLER, D., \& PHILLIPS, E.R., 1989. Correlation of the Monian Supergroup in NW Anglesey with the Cahore Group in SE Ireland. Journal of the Geological Society, London 141, 417418.

TURNER, J.S. 1936. The structural significance of the Rossendale Anticline. Transactions of the Leeds Geological Association 5, 157-160.

VAN STAAL, C.R., DEWEY, J. F., MACNIOCAILL, C., \& MCKERROW, S. 1998. The CambrianSilurian tectonic evolution of the northern Appalachians: History of a complex, southwest Pacifictype segment of lapetus. In: BLUNDELL, D. J., \& SCOTT, A. C. (eds.) Lyell: the Past is the Key to the Present. pp. 199-242.Geological Society, London, Special Publication 143.

WALDRON, J.W.F., Schofield, D.I., DuFrane, S.A., FloYD, J.D., Crowley, Q.G., SimonetTI, A., DOKKEN, R.J. \& POTHIER, H.D., 2014. Ganderia-Laurentia collision in the Caledonides of Great Britain and Ireland: Journal of the Geological Society, London 171, 555-569.

WALDRON, J.W.F., SCHOFIELD, D.I., WHITE, C.E., \& BARR, S.M. 2011. Cambrian successions of the Meguma Terrane, Nova Scotia, Canada, and Harlech Dome, North Wales, UK: dispersed fragments of a peri-Gondwanan basin? Journal of the Geological Society, London 168, 83-98.

WALDRON, J.W.F., SCHOFIELD, D.I. \& MURPHY, J.B. 2018 Diachronous Paleozoic accretion of periGondwanan terranes at the Laurentian margin. Geological Society, London, Special Publication 470, https://doi.org/10.1144/SP470.11

WALDRON,J.W.F., SCHOFIELD, D.I., PEARSON, G., Fisher, M., LuO, Y., SARKAR, C. \& DOKKEN, R. in press. Laser ablation split-stream (LASS) characterization of early Cambrian sandstones from East Avalonia and SE Ireland: implications for terrane affinities in the peri-Gondwanan Caledonides. Geological Magazine.

WARNER, M.R., 1986. Deep seismic reflection profiling the continental crust at sea. In: :

BARAZANGI, M., BROWN, L. (eds.). Reflection Seismology: A Global Perspective. American Geophysical Union Geodynamic Series 13, 301-311.

WATERS, C.N., WATERS, R.A., BARCLAY, W.J. \& DAVIES, J.R. 2009. A lithostratigraphic framework for the Carboniferous successions of southern Great Britain (onshore). British Geological Survey Research Report, RR/09/01.

WOODCOCK, N.H., \& STRACHAN, R.A. 2012. (eds.). Geological History of Britain and Ireland. 442pp. (Oxford: Blackwell Publishing Ltd.) 2nd ed.

WoOdCOCK, N.H. \& SOPER, N.J. 2006. The Acadian Orogeny: The mid-Devonian phase of deformation that formed slate belts in England and Wales. In: BRENCHLEY, P.J. \& RAWSON, P.F. (eds) 2006. The Geology of England and Wales. Second Edition. Geological Society, London, 103129. 
WOODWARD, K. \& CURTIS, C. D. 1987. Predictive modelling of the distribution of production constraining illites - Morecambe Gas Field, Irish Sea, Offshore UK. In: BROOKS, J. \& GLENNIE, K. (eds.). Petroleum Geology of North West Europe. (London: Graham \& Trotman) 205-215.

WRIGHT, W.B., SHERLOCK, R.L., WRAY, D.A., LLOYD, W. \& TONKS, L.H. 1927. The geology of the Rossendale Anticline. Memoir of the Geological Survey, Sheet 76 (England \& Wales).

\section{List of figures}

Fig. 1. Simplified map of Caledonian terrane relationships in southern Britain and eastern Ireland, modified from Pharaoh (2018), to show the location of the area of interest. Caledonian terrane boundaries south of the Iapetus Suture are slightly modified after Bluck (1992) and BGS (1996). The boundary between the Lakesman-Leinster Terrane and Wexford-Monian-Ingleton Terrane ('Irish Sea Horst', and probable Ganderian correlative) follows Soper \& Dunning (2005). Key to faults and lineaments: AL, Askrigg Line; BAF, Bala Fault; BEF, Bryneglwys Fault; BMZ, Ballycogly Mylonite Zone; CHT, Carmel Head Thrust; CPFS, Causey Pike Fault System, CSF, Church Stretton Fault Zone; DL, Dent Line; D-SHL, Dowsing-South Hewett Lineament; EGL, Eakring-Glinton Lineament; FHFZ, Vale of Pickering-Flamborough Head Fault Zone; IS, Iapetus Suture Zone; ISLS, Irish Sea Lineament (South); LEF, Lask Edge Fault; LLF, Lowther Lodge Fault; LSZ, Lŷn Shear Zone; MCEM?, Conjectured Microcraton Eastern Margin; MCFZ, Morley-Campsall Fault Zone; MCWM, Microcraton NW Margin; MDFB, Môn-Deemster Fold-Thrust Belt; ML, Malvern Line; MSFS, Menai Strait Fault System; PA, Pennine Axis; PL, Pendle Lineament; PLL, Pontesford-Linley Fault; RFB, Ribblesdale Foldbelt, N margin; RRF, Red Rock Fault; SBL, Southern Borrowdale Lineament; SCF, South Craven Fault; ST, Skiddaw Thrust; TF, Thringstone Fault; UF, Unnamed Fault; VF, Variscan Front; WF, Wem Fault; WBFS, Welsh Borderland Fault System.

Fig. 2. Pre-Quaternary geological map of the East Irish Sea Basin and environs, showing relationship of the concealed Môn-Deemster FTB in the offshore to the Ribblesdale FTB of the Lancashire onshore. The key to the geology covers the most significant rock units, as described in the text. For further information on more detailed stratigraphy, the reader is referred to the BGS 1:625 000 Bedrock Geology Map and 1:250 000 East Irish Sea and St George's Channel special sheets. Variscan inversion anticlines shown as black dashed lines. Key to localities mentioned in the text: AB, Askrigg Block; BB, Bowland Basin; CAB, Carnarfon Basin; CHB, Cheshire Basin; CISB, Central Irish Sea Basin; CRB, Craven Basin; CLH, Central Lancashire High; DP, Deemster Platform; EDB, East Deemster Basin; Fo, Formby; Fy, Fylde; GCB, Godred Croven Basin; H, Horton in Ribblesdale Inlier; HB, Harrogate Basin; HIS, Holy Island Shelf; I, Ingleton Inlier; IOM, Isle of Man; LDM, Lake District Massif; NWM, North Wales Massif; OI, Ogham Inlier.

Fig. 3. Pre-Permian subcrop map of the southern Irish Sea and environs showing mapped Variscan inversion structures (dashed black lines) and key boreholes. Exploration wells penetrating Carboniferous strata offshore from OGA website. Seismic profiles and cross-section lines described in the text are shown in purple. Stratigraphic key: UORS, Upper Old Red Sandstone; CL Sgp, C Gp and A Fm, Carboniferous Limestone Supergroup, Craven Group and Alston Formation (northern England); MG and Y Gps, Millstone Grit and Yoredale (northern England) groups; PCM Gp, Pennine Coal Measures Group; W Gp. Warwickshire Group. Key to abbreviated tectonic elements in caption to Figure 2.

Fig. 4. Geological map and cross-sections of the Ribblesdale Fold-Thrust Belt (onshore). 
a. Mapping after Kirby et al. (2000), showing location of cross-sections (Fig. 4b, c) and seismic sections (Fig. 5a, b) depicted in the text. Key to geology as in Fig. 3. Abbreviated structural features: BAF, Bolton Abbey Fault; BaF, Barnoldswick Fault; BoL, Bowland Line; C-AF, Clitheroe-Abbeystead Fault; ClA, Clitheroe Anticline; DeF, Dent Fault; DiA, Dinkley Anticline; DWF, Darwen Valley Fault; GiA, Gisburn Anticline; HaA, Harrogate Anticline; HeF, Heywood Fault; HtF, Hollintree Fault; HoF, Holme Fault; HuM, Hutton Monocline; LDB, Lake District Boundary Fault; LoA, Lothersdale Anticline; MCF, Mid Craven Fault; NCF, North Craven Fault; NNA, Nicky Nook Anticline; PeA, Pennine Anticline; PeF, Pennine Reverse Fault; PeM, Pennine Monocline; PFS, Pendle Fault System; PM, Pendle Monocline; RoA, Rossendale Anticline; SCF, South Craven Fault; SkA, Skipton Anticline; SlA, Slaidburn Anticline; SyA, Sykes Anticline; ThA, Thornley Anticline; TA, Thornton Anticline; WDB, West Deemster Basin; WeA, Wheatley Anticline.

b. Cross-section across the Thornley Anticline at northern margin (adapted from Aitkenhead et al. 1992). Location shown on Figs. 3 and 4a. Visean (undifferentiated) compises Craven Group (Hodder Mudstone Formation and Lower Bowland Shale Formation); Namurian comprises Upper Bowland Shale Formation and the Millstone Grit Group.

c. Cross-section across the Lothersdale Anticline and Pendle Fault at southern margin (adapted after Kirby et al. 2000). Location shown on Figs. 3 and 4a. Visean (undifferentiated) compises Craven Group (Hodder Mudstone Formation and Lower Bowland Shale Formation); Namurian comprises Upper Bowland Shale Formation and the Millstone Grit Group.

Fig. 5. Interpreted seismic transects of the Ribblesdale FTB and Bowland Basin (onshore). Locations shown in Figs. 3 and 4a. 2D seismic reflection data kindly supplied by UKOGL.

a. Transect D, crossing the largely concealed Variscan fold belt of the West Lancashire (Fylde and Formby areas), as imaged by the oblique UKOGL-RG-006 regional transect (Butler \& Jamieson, 2013). Note that the Woodsfold Fault (WF) is intersected twice in this transect; PF; Pendle Fault System; TtF, Thistleton Fault.

b. Transect E, crossing the Ribblesdale FTB at crop in the Bowland Basin N.B. Major inversion folds above the Bowland Line (BL) in the north show vergence to NW, those above the Pendle Fault (PF) System in the south, show vergence to SE, so that the Ribblesdale FTB has the gross appearance of a positive flower structure.

Fig. 6. Cross-sections of the Môn-Deemster FTB (offshore), based on 2D seismic reflection data kindly supplied by IHS Global Limited (110-86/87 lines) and Conoco-Phillips (through CDA) for a short northward extension onto the Deemster Platform (BG923 survey). Locations shown in Figs. 3 and 7. Permian-Mesozoic basin features are labelled in red; Carboniferous and Variscan features labelled in dark blue.

a. Transect A, located 10-15 km east of Anglesey, crosses the Godred Croven Basin, Berw Basin and strands of the Menai Strait Fault System (BF, Berw Fault; DF, Dinorwic Fault) before crossing onto the Conwy Platform in the south. A southward-dipping syndepositional fault (NMF) defining the northern margin of the offshore Bowland Basin is developed in the hangingwall of a late Caledonian thrust. The thrust is mapped on the seismic data westward to Anglesey, and correlated with the exposed Carmel Head Thrust (CHT). Offshore, the latter appears to imbricate deeper crustal structure, including the zone of enhanced mid-crustal reflectivity (dashed white lines) here correlated with the Penmynydd Zone 
(PZ). The Berw Fault is part of the Menai Strait Fault System, defining the en échelon southern margin (SMF) of the offshore Bowland Basin in this transect. The strong folding of Permo-Triassic strata showing low discordance to underlying Carboniferous strata, in the Seriol Anticline, is interpreted as Alpine deformation probably facilitated by halokinesis.

b. Transect C, crossing the Deemster Platform and Foryd Basin. Note the complex structure of the MônDeemster FTB beneath the thin Permo-Triassic cover of the Deemster Platform. The white pick is the 'Top platy-illite zone' reflector inferred to be a palaeo-hydrocarbon/water contact of Jurassic age (Bushell 1986, Woodward \& Curtis 1987). Its tilting indicates significant Alpine deformation.

Fig. 7. Map of concealed Mississippian basins (grey shaded ornament superimposed on tectonic elements from Fig. 3) and Variscan compressional structures in the southern Irish Sea and environs. For key to abbreviated labels see caption to Fig 3.

Fig. 8. a. Map of the Llandudno, North Wales area, showing the relationship of the Carboniferous basins to the Aber-Dinlle strand of the Menai Strait Fault System. Modified from Needham \& Morgan (1997). b. Cross-section through the Great Orme and Gloddaeth synclines (Transect W on Figs. 3 and 7). Modified from Needham \& Morgan (1997).

Fig. 9. Simplified geological map of Anglesey and the Llŷn Peninsula (modified after BGS 2009). The upper surface of the Penmynydd Zone (equivalent to the Berw Shear Zone at crop) in TWTT (ms), mapped using BIRPS and available commercial data in the vicinity of Anglesey. Location of co-located deep reflection profiles (Transect Y) in Fig. 10 is shown in black (WINCH-4) and red (SWAT-0, -0A).

Fig. 10. Schematic cross-section across Anglesey (Transect $\mathrm{X}$ ) to show inferred relationship of major lithotectonic units within the Penobscotian basement complex, and relationship to later Ordovician, Silurian, Devonian and Carboniferous cover sequences. Location shown on Figs. 3, 7 and 9. Note the inferred (?Acadian) imbrication of the $3 \mathrm{~km}$ thick 'Penmynydd Zone' and its exhumation by the post-Acadian Menai Strait Fault System; and extensional reactivation in the hangingwall of Penobscotian and Acadian compressional structures (e.g. the Carmel Head Thrust) in later Palaeozoic time.

Fig. 11. Co-located BIRPS deep seismic profiling SW of Anglesey and the Llŷn Peninsula. Location shown in Figs. 3, 7 and 9. The red rectangle shows the position of SWAT-0/0A with respect to WINCH4. The Penmynydd Zone ('PZ', bounded by white dashed lines) is identified as a NW-dipping zone of enhanced reflectivity 3-4 km thick, reaching crop on the Llŷn Peninsula. Key to abbreviations: CISB, Central Irish Sea Basin; LSZ, Llŷn Shear Zone; PZ, Penmynydd Zone. Horizon pick colours: Yellow, Base Quaternary; Pink, Top Sherwood Sandstone Group; Dark blue, Base Calder Sandstone; Pale blue, Top Permian; Orange, Base Permian-Variscan Unconformity; Red, Base Carboniferous.

Fig. 12. Preliminary results of section-balancing for the five transects across the Môn-DeemsterRibblesdale FTB shown in Figs. 3 and 7, and based on the seismic profiles shown in Fig. 6. Left hand side, Present day situation; right hand side, restoration to late Carboniferous time (flattened to Base Cumbrian Coast Group). a. westernmost offshore profile, illustrating multiple reactivation of Carmel Head Thrust and its hangingwall (based on Fig. 6a); b. central offshore profile (based on Fig. 3 of Pharaoh et al. 2018); c. easternmost offshore profile, running from the West Deemster Basin, across the Deemster Platform towards the N Wales coast (based on Fig. 6b); d. onshore transect close the coast, crossing the Formby and Fylde basins and based on UKOGL regional line RG006 (based on Fig. 5a); e. onshore transect across the exposed Bowland Basin (based on Fig. 5b). 
Fig. 13. Schematic diagram to illustrate the pre-Jurassic structural evolution of the SE Irish Sea region.

A. EARLY ORDOVICIAN: Penobscotian Phase

1. Gondwana margin comprising Megumian or Avalonian-type volcanic and sedimentary sequences plus Cambrian-early Tremadoc sedimentary cover.

2. Ganderian Terrane.

3. Gently inclined zone of enhanced reflectivity interpreted as a crustal mega-shear zone (Penmynydd Zone, PZ).

4. Lower boundary of Penmynydd Zone, correlative with the Llŷn Shear Zone (LSZ).

B. LATE ORDOVICIAN: Iapetus-Tornquist subduction beneath East Avalonia Microcontinent.

1. Subduction-related volcanic and sedimentary sequences (e.g. Lake District, Eastern England).

2. Back-arc volcanic and marginal-basin (e.g. Welsh Basin).

3. Penmynydd Zone (PZ) largely concealed beneath northern edge of Welsh Basin, but locally exposed as the Llŷn Shear Zone.

C. EARLY DEVONIAN: Acadian Phase

1. Crustal imbrication by the Carmel Head Thrust (CHT).

2. Acadian thrust.

3. Harlech Dome.

4. Folded upper boundary of Penmynydd Zone.

5. Thickened wedge of Penmynydd Zone within crustal duplex.

D. EARLY-MID CARBONIFEROUS: Mississippian Extension and Pennsylvanian Thermal Subsidence.

1. Initiation of Lagman-Eubonia Fault System at southern margin of granite-underpinned ManxFurness High (MFH), controls subsidence of Eubonia Tilt-block (ETB).

2. Eubonia Tilt-block containing up to $7 \mathrm{~km}$ of Carboniferous Limestone Supergroup, Millstone Grit Group and Pennine Coal Measures Supergroup strata.

3. Extensional faulting develops in the hangingwall of the Acadian Carmel Head Thrust (northern boundary of the Bowland Basin, BB).

4. Extensional reactivation of another Acadian thrust.

5. Extensional fault forming part of the en échelon southern boundary of the Bowland Basin (BB) e.g. the Berw, Dinorwic and Aber-Dinlle faults (Menai Strait Fault System, MSFS), bounding the Conwy Platform (CP).

E. LATE CARBONIFEROUS-EARLY PERMIAN: Variscan Inversion.

1. Mild inversion of the southern edge of the Eubonia Tilt-block enhances the Quadrant 109 Arch.

2. Erosion of rising anticlines and deposition of Warwickshire Group ('barren red measures') strata in synclines.

3. Inversion against buttress of Manx-Furness High.

4. Inversion adjacent to original extensional faults in the Bowland Basin produces folding and thrusting in the Môn-Deemster-Ribblesdale (MDR) FTB, above a detachment at the reactivated Carmel Head Thrust Zone (RCHTZ).

F. LATE PERMIAN-TRIASSIC-JURASSIC: Extension and Subsidence

1. Over $7 \mathrm{~km}$ of subsidence in Keys Basin controlled by Lagman and Keys faults.

2. Variable thickness of Permian strata deposited, in part reflecting residual topographic relief on the Variscan Unconformity. 
3. W-E extension results in limited extensional reactivation of Carboniferous faults, although both the Berw and Aber-Dinlle faults show post-Triassic displacement.

4. New extensional faults initiated on a N-S trend, reflecting W-E extension.

5. Preservation of Warwickshire Group strata locally at margins of the East Irish Sea Basin.

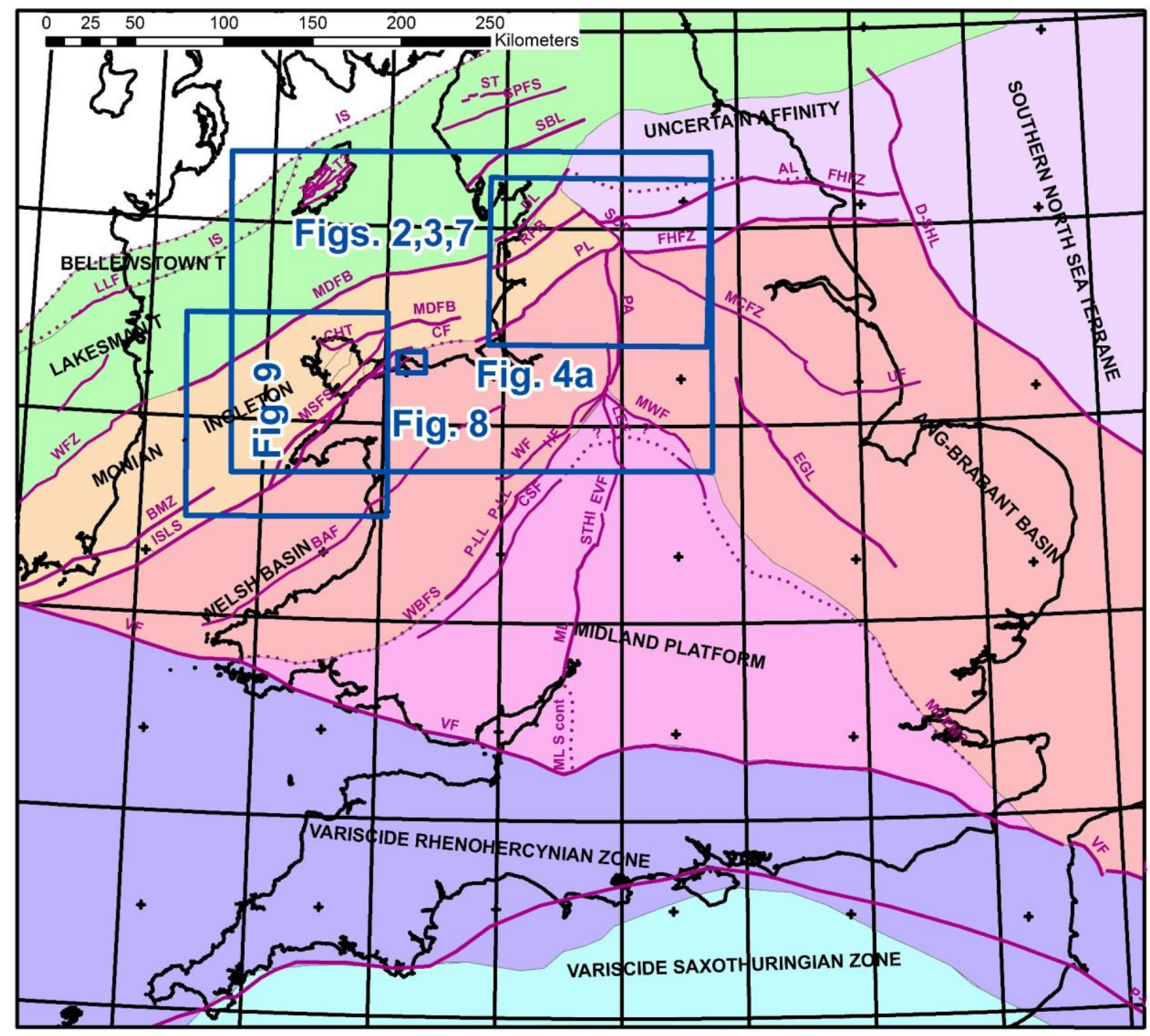

Fig 1 


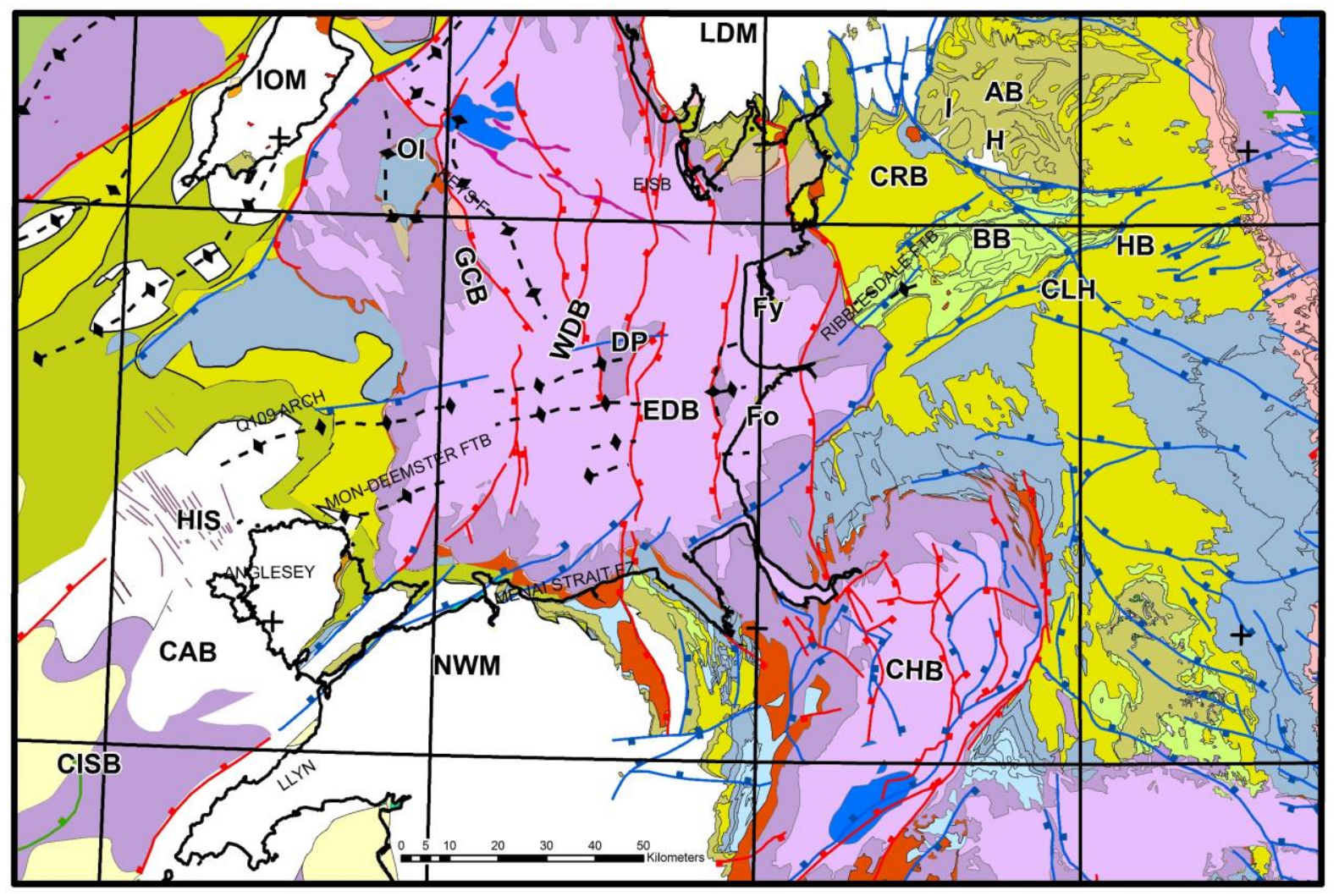

Key to bedrock geology

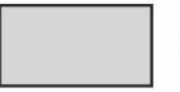

Warwickshire Group

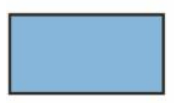

Pennine Coal Measures Gp

Millstone Grit \& Yoredale Gps

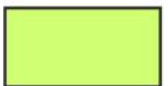

Craven Gp \& Bowland Shale Fm

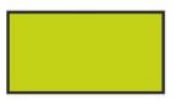

Carboniferous Lst Sgp \& Alston $\mathrm{Fm}$

Devonian

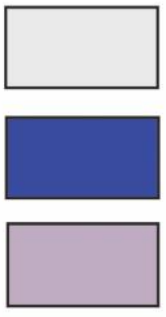

Cenozoic

Jurassic

Triassic Mercia Mudstone $\mathrm{Gp}$ \& Penarth Group

Triassic Sherwood Sst Gp

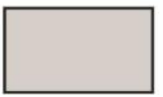

Permian Cumbrian Coast Gp

Permian Appleby Group

Neoproterozoic-Early
Palaeozoic undivided

Fig 2 


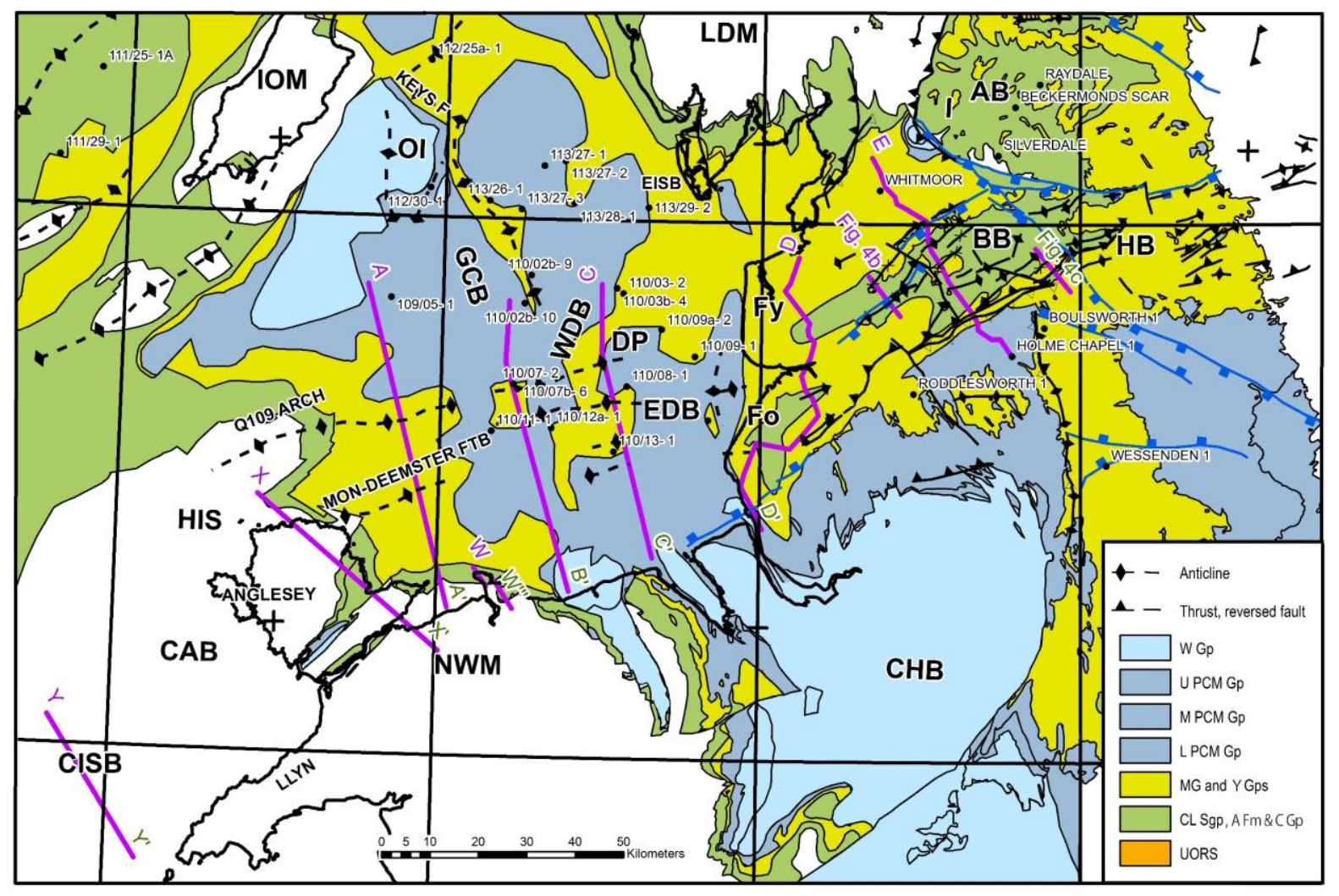

Fig 3 

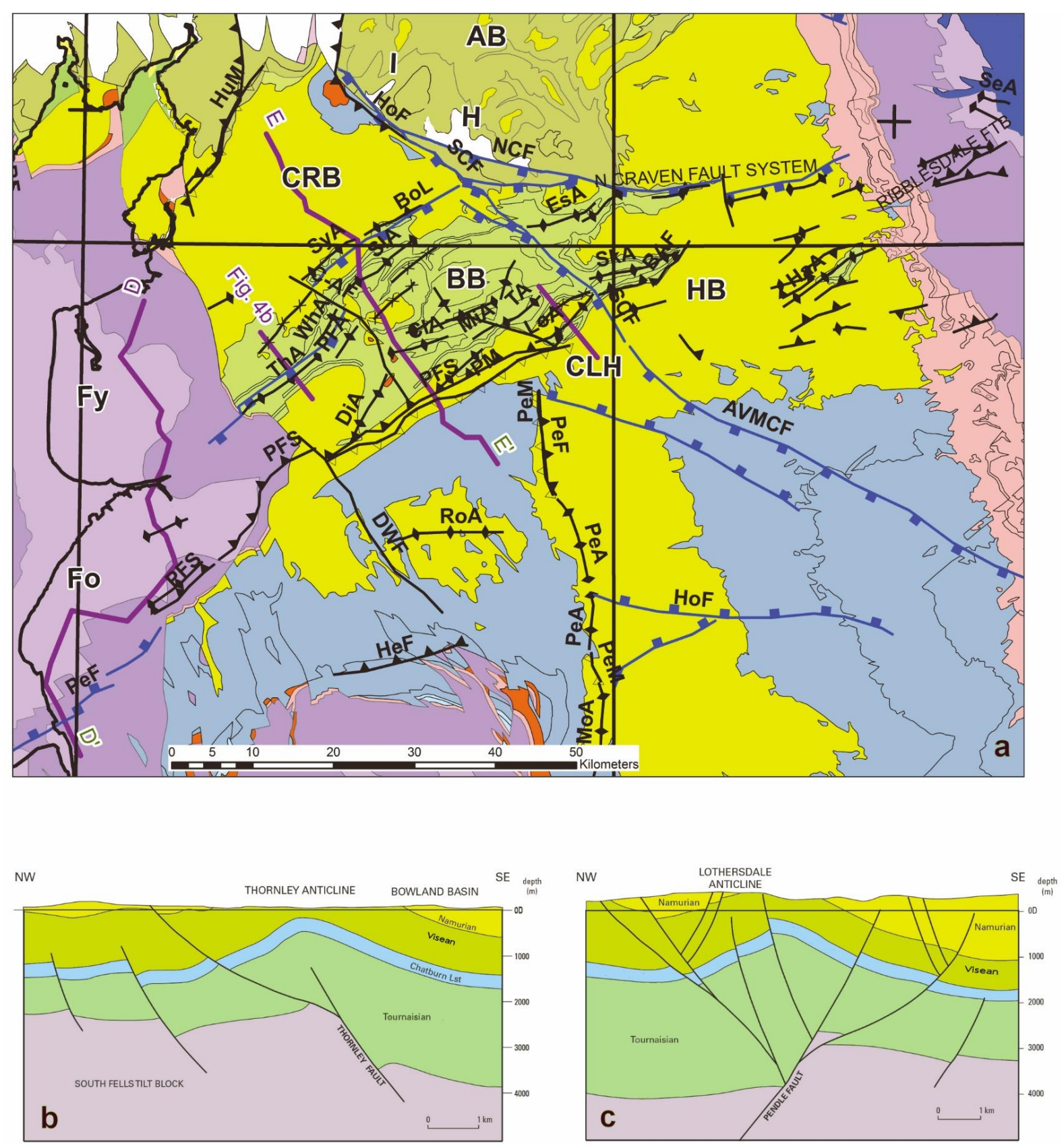

Fig 4 

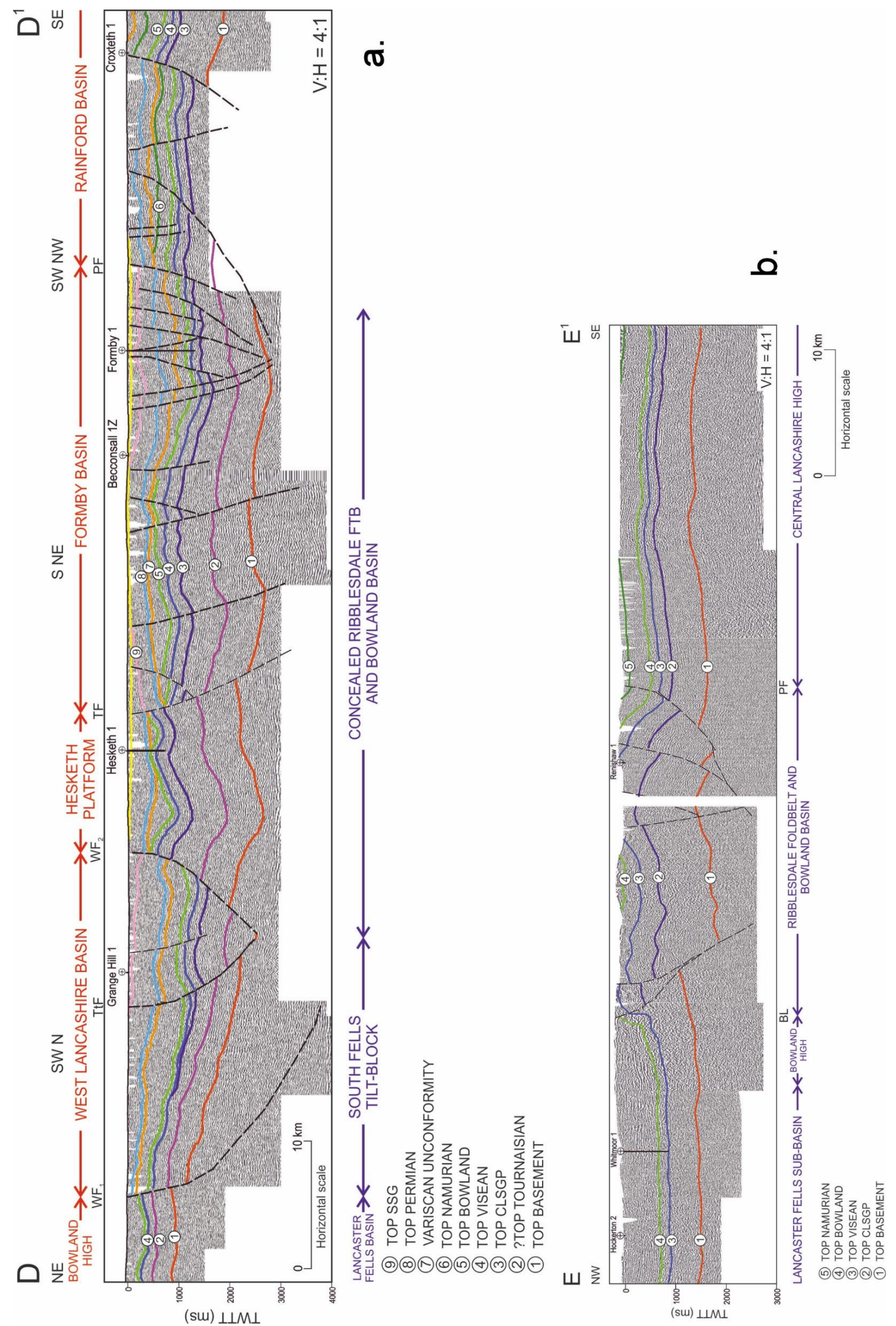

Fig 5 

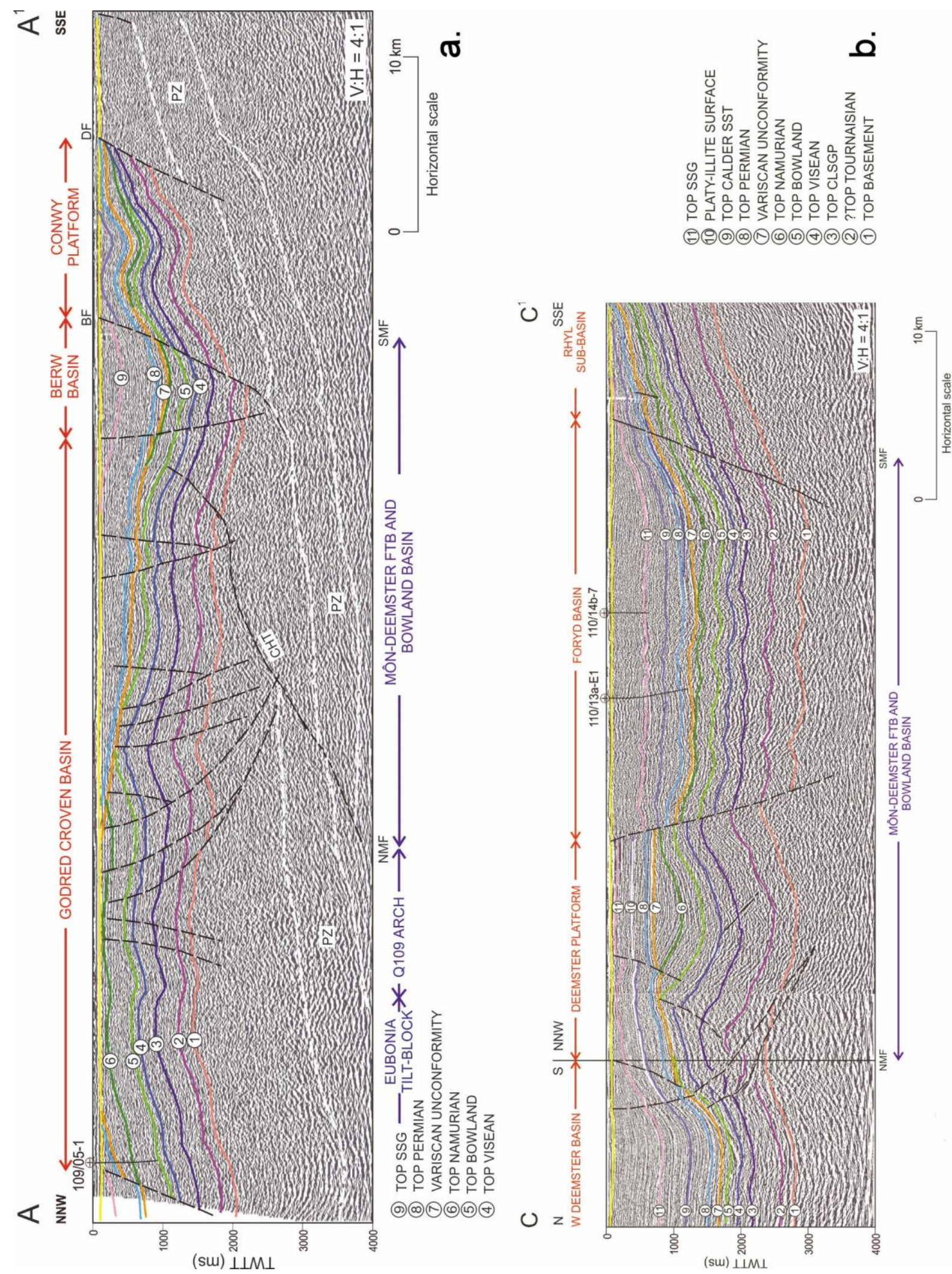

Fig 6 


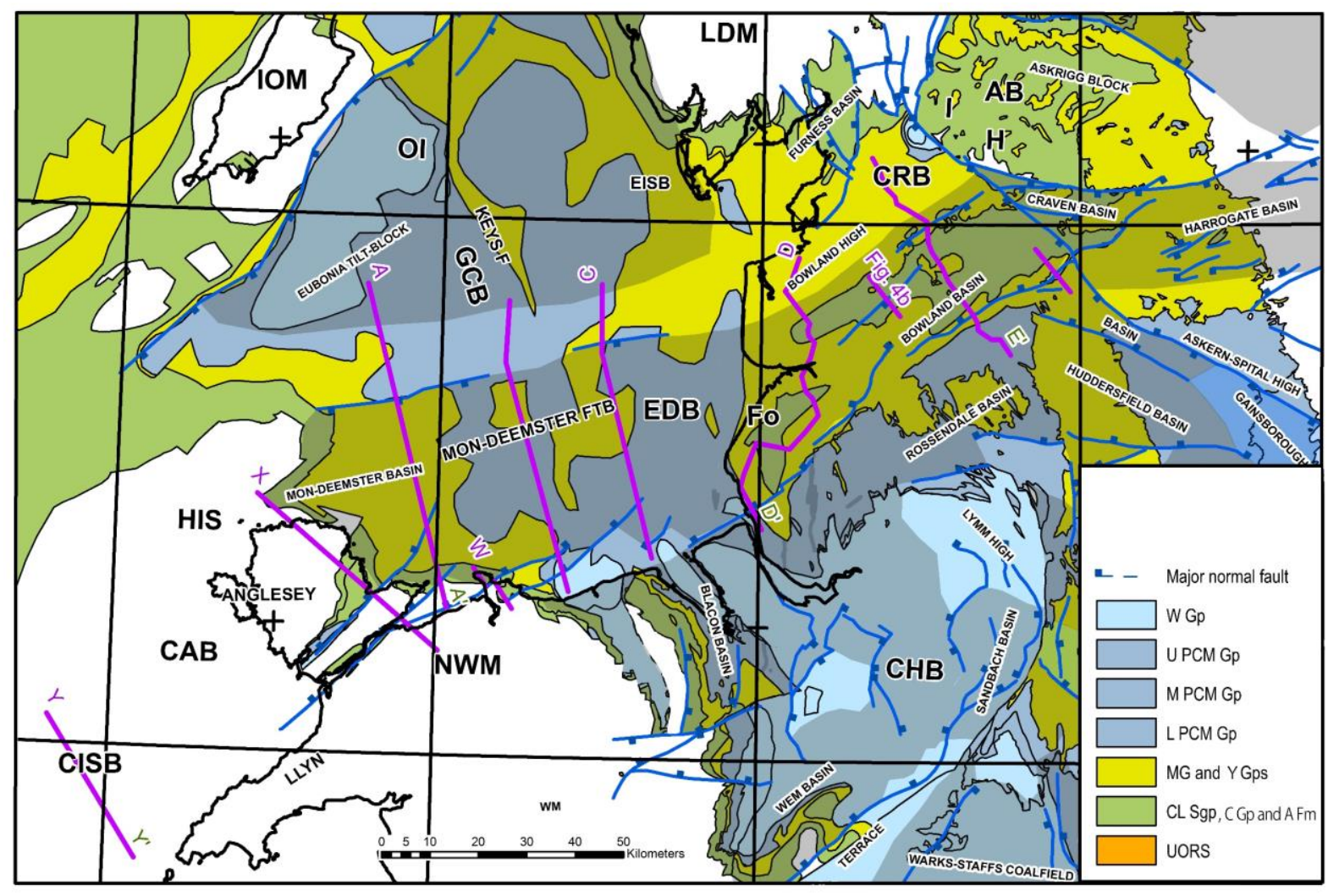

Fig 7 


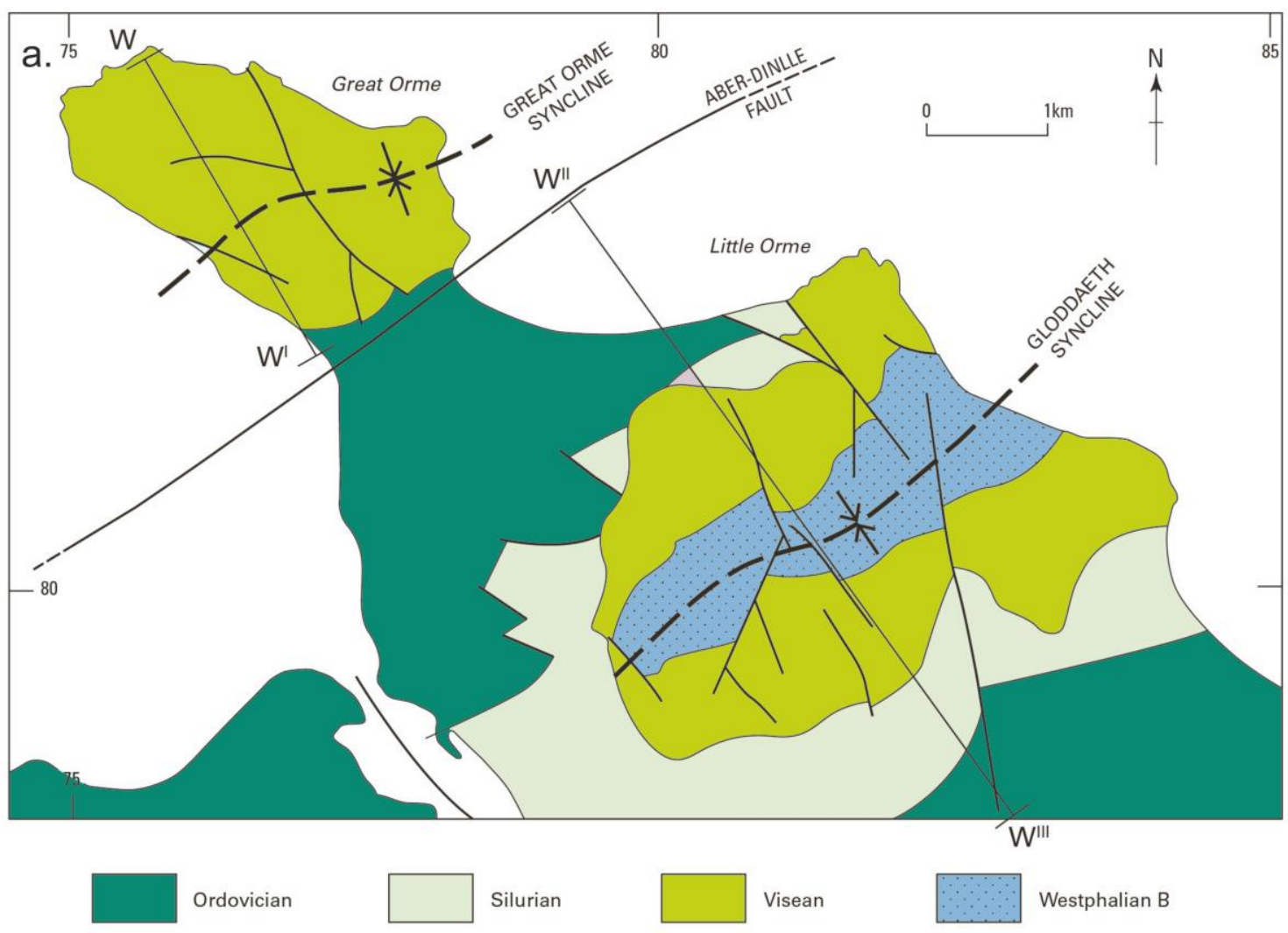

NE

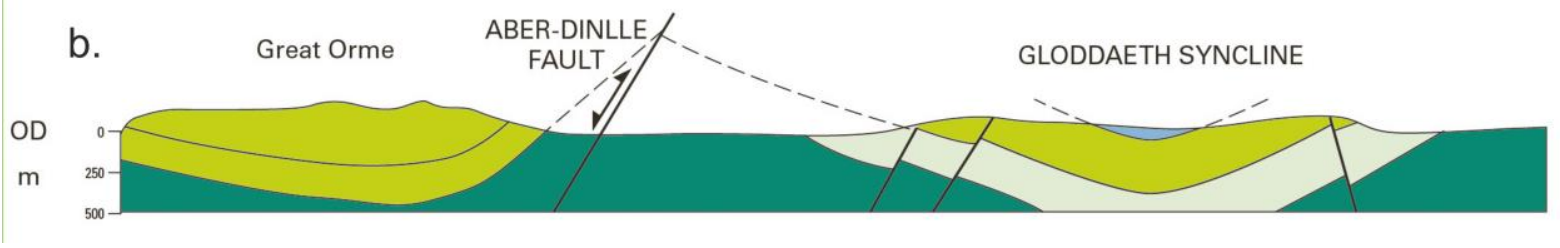

Fig 8 


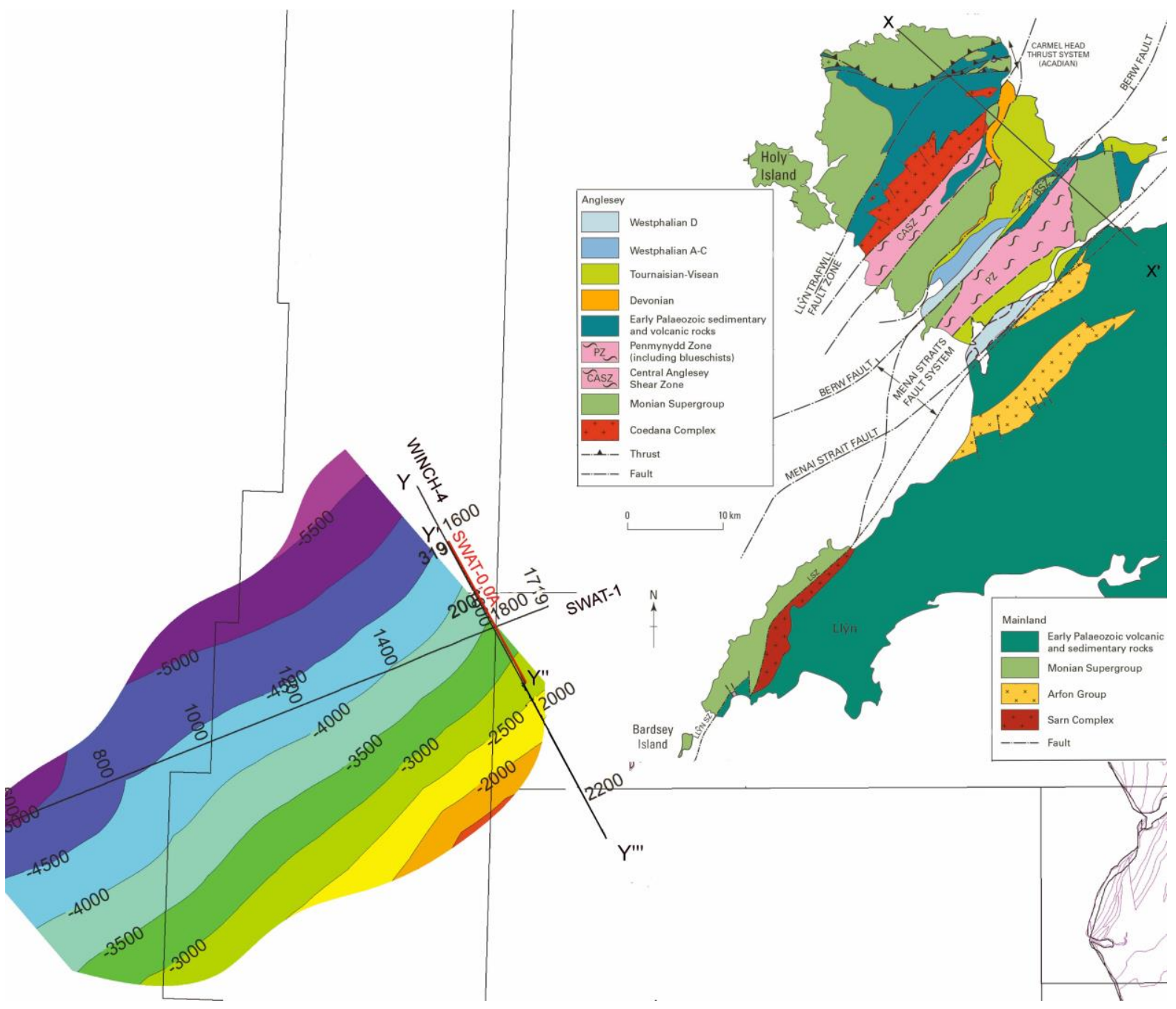

Fig 9 


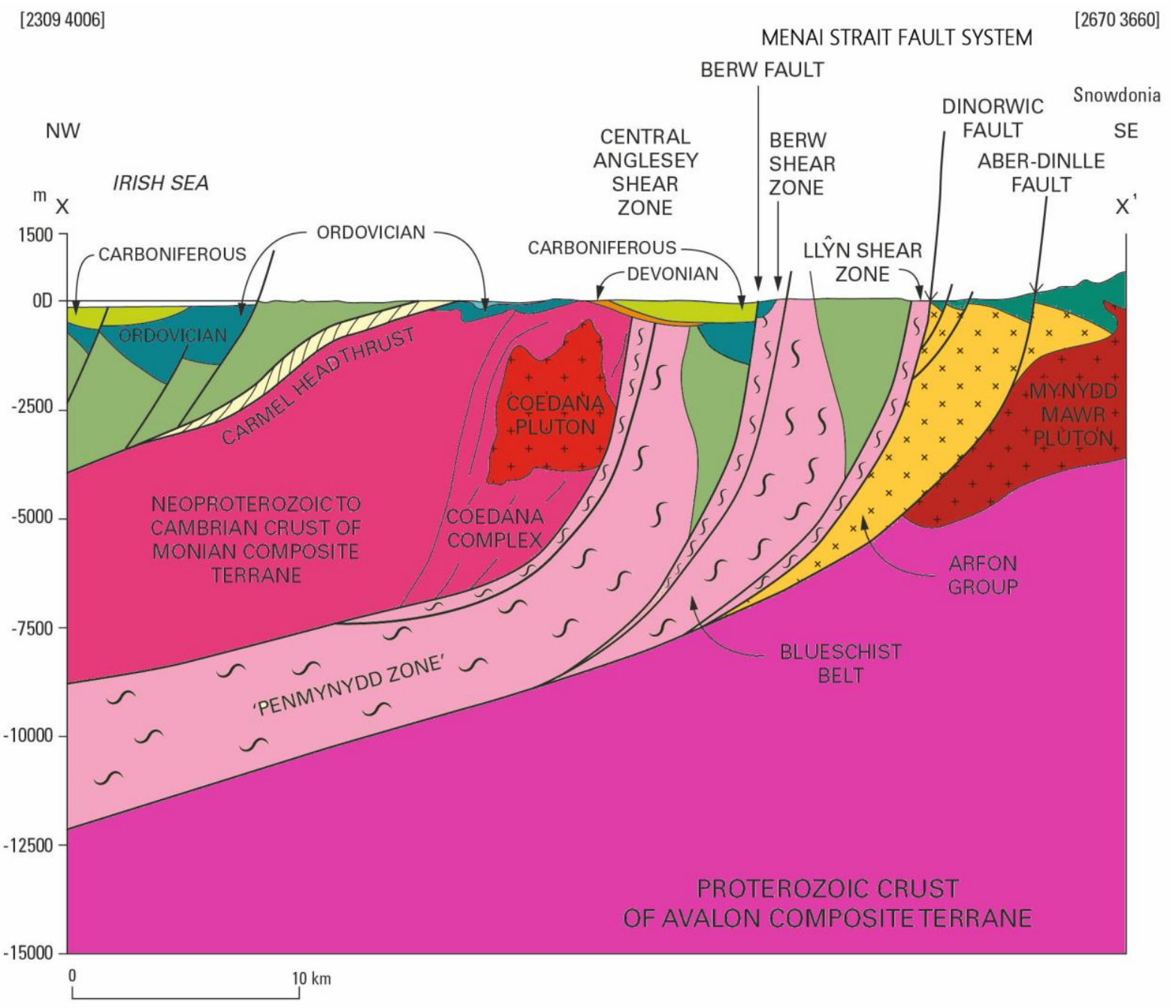

Fig 10 

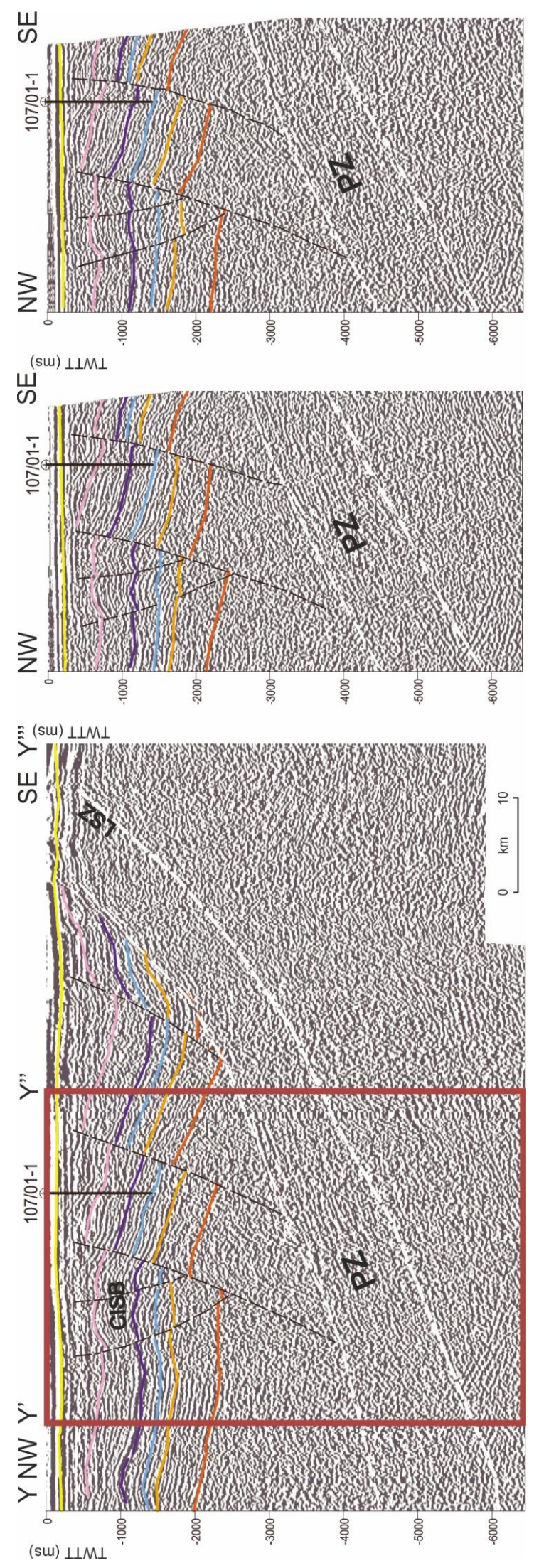

Fig 11 

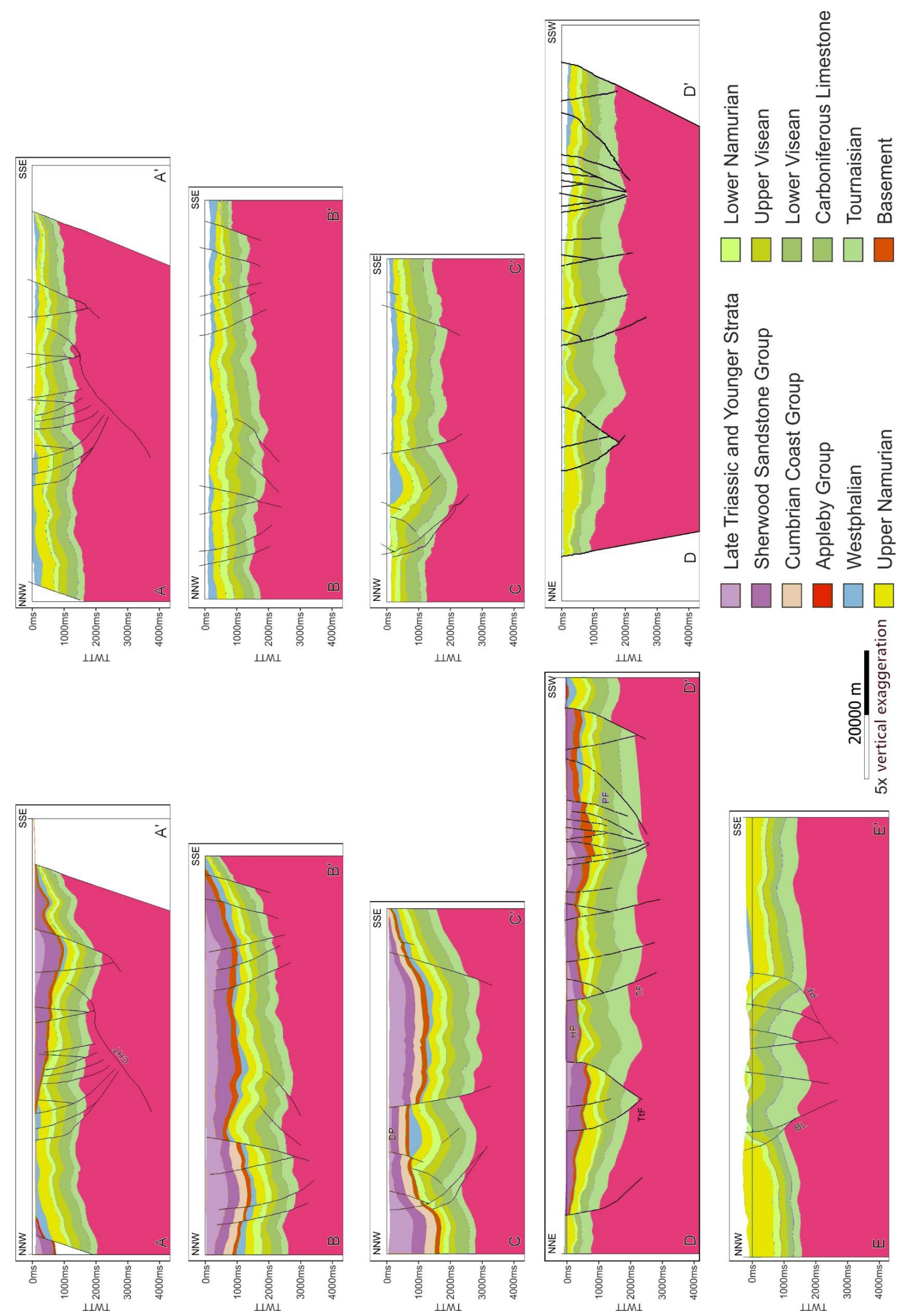

Fig 12 
A. EARLY ORDOVICIAN

PENOBSCOTIAN PHASE

B. LATE ORDOVICIAN

IAPETUS-TORNOUIST

CLOSURE

C. EARLY DEVONIAN

ACADIAN PHASE

\section{EARLY-MID \\ CARBONIFEROUS}

MISSISSIPPIAN-

EXTENSION AND

PENNSYLVANIAN

SUBSIDENCE

\section{E. LATE CARBONIFEROUS EARLY PERMIAN}

VARISCAN INVERSION

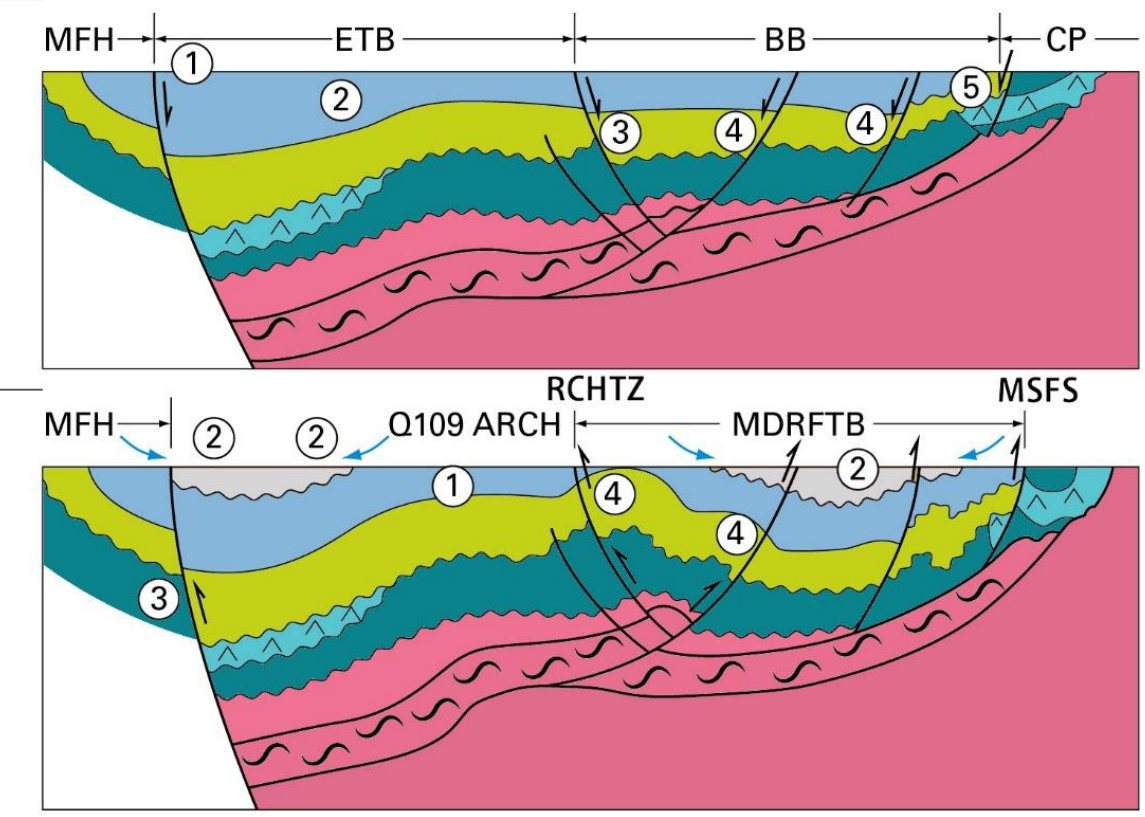

F. LATE PERMIANJURASSIC

RIFTING EXTENSION AND SUBSIDENCE
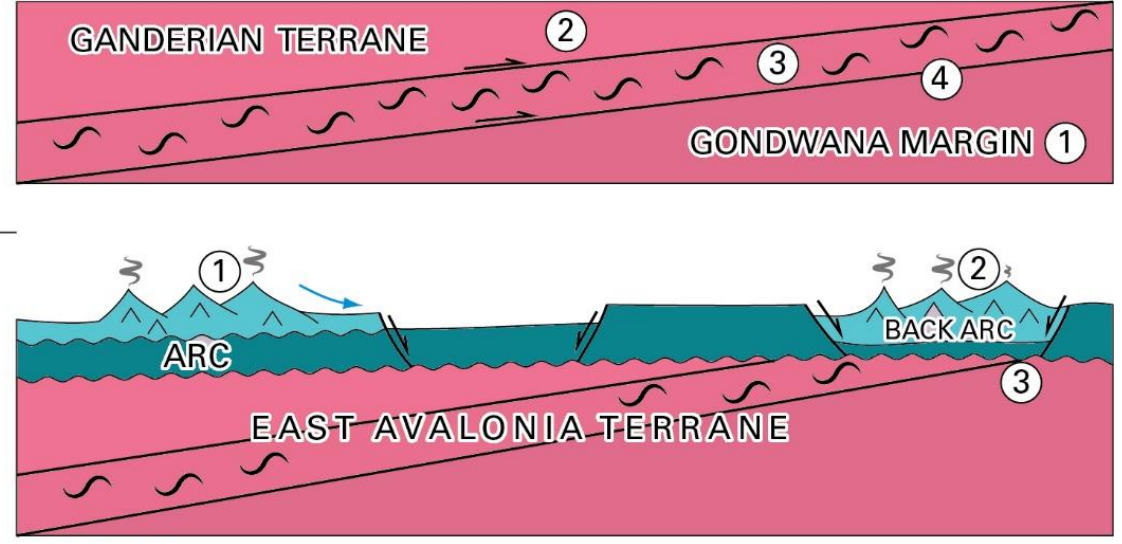

(1)

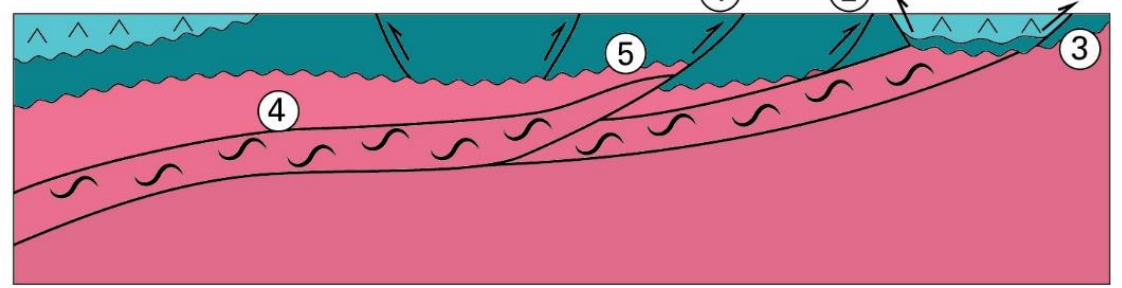

(3) 